NBER WORKING PAPER SERIES

\title{
WILL THE SECULAR DECLINE IN EXCHANGE RATE AND INFLATION VOLATILITY SURVIVE COVID-19?
}

\author{
Ethan Ilzetzki \\ Carmen M. Reinhart \\ Kenneth S. Rogoff \\ Working Paper 28108 \\ http://www.nber.org/papers/w28108 \\ NATIONAL BUREAU OF ECONOMIC RESEARCH \\ 1050 Massachusetts Avenue \\ Cambridge, MA 02138 \\ November 2020
}

We thank Clemens Graf von Luckner for his outstanding research assistance and Andrew Lilly for his comments and sharing the CVIX data. A version of this paper will appear Brookings Panel on Economic Activity, Fall 2020. The authors are grateful to editors Janice Eberly and James Stock, to our discussant Silvia Miranda-Agrippino and well as Brookings panel participants for helpful comments. We are also grateful to Barbara Rossi for useful suggestions. The views expressed in this article are those of the authors and do not necessarily reflect the official policy or position of the World Bank or the National Bureau of Economic Research.

NBER working papers are circulated for discussion and comment purposes. They have not been peer-reviewed or been subject to the review by the NBER Board of Directors that accompanies official NBER publications.

(C) 2020 by Ethan Ilzetzki, Carmen M. Reinhart, and Kenneth S. Rogoff. All rights reserved. Short sections of text, not to exceed two paragraphs, may be quoted without explicit permission provided that full credit, including $(\odot$ notice, is given to the source. 
Will the Secular Decline In Exchange Rate and Inflation Volatility Survive COVID-19?

Ethan Ilzetzki, Carmen M. Reinhart, and Kenneth S. Rogoff

NBER Working Paper No. 28108

November 2020

JEL No. E5,F3,F4,N2

\begin{abstract}
$\underline{\text { ABSTRACT }}$
Over the 21st century, and especially since 2014, global exchange rate volatility has been trending downwards, notably among the core G3 currencies (dollar, euro and the yen), and to some extent the G4 (including China). This stability continued through the Covid-19 recession to date: unusual, as exchange volatility generally rises in US recessions. Compared to measures of stock price volatility, exchange rate volatility rivals the lows reached in the heyday of Bretton Woods I. This paper argues that the core driver is convergence in monetary policy, reflected in a sharp-reduction of inflation and short- and especially long-term interest rate differentials. This unprecedented stability, which partially extends to emerging markets, is strongly reinforced by expectations that the zero bound will be significantly binding for advanced economies for years to come. We consider various hypotheses and suggest that the shutdown of monetary volatility is the leading explanation. The concluding part of the paper cautions that systemic economic crises often produce major turning points, so a collapse of the Extended Bretton Woods II regime cannot be ruled out.

Ethan Ilzetzki

London School of Economics

Houghton Street

London WC2A 2AE

e.ilzetzki@LSE.ac.uk

Carmen M. Reinhart

Kennedy School of Government

Harvard University

79 JFK Street

Cambridge, MA 02138

and CEPR

and also NBER

carmen_reinhart@harvard.edu

Kenneth S. Rogoff

Thomas D Cabot Professor of Public Policy

Economics Department

Harvard University

Littauer Center 216

Cambridge, MA 02138-3001

and NBER

krogoff@harvard.edu
\end{abstract}


One of the most surprising features of the Covid-19 shock has been the stunning stability in exchange rates, despite an epic global recession. True, although the yen-dollar rate has barely moved, the exchange rate between the euro and dollar has appreciated 6\% (as of this writing). But to put this in perspective, over the course of 2008 financial crisis, the dollar-euro rate gyrated between 1.58 and 1.07, the yen-dollar between 90 and 123. In this paper, we show that increasing G3 global exchange rate stability during Covid (so far) is an acceleration of a barelystudied longer-term trend. ${ }^{1}$ Incorporating China into a G4 that encompasses half of global GDP only strengthens the point. Figure 1 illustrates this fact, showing the decline in dollar-yen (top panel) and dollar-euro (or dollar-Deutschemark, bottom panel) exchange rate variability since the mid-1970s.

For the moment, the world is in an "Extended Bretton Woods II" exchange regime, where not only are developing Asian currencies stable against the dollar, but also much of the OECD, including Europe and Japan. Indeed, we will show that in some respects Extended Bretton Woods II has now lasted as long as the open capital markets period of Bretton Woods I and has been more encompassing in terms of global GDP. Recent stability in the core global exchange rate system does not yet match the best years of the post-war Bretton Woods I system, but it is even more stable when compared to stock price volatility. (See Figure 2 below.)

What is going on and what might the missing volatility portend for the future of the global exchange rate system, not just at the center but for emerging markets and the periphery? We will argue that a central driving force has been a collapse in international short-term and long-term interest differentials combined with an assumption in markets that the effective lower bound on interest rates is here to stay for a very long time. Relative volatility in conventional monetary policy has apparently been removed from the table for an extended period. The collapse of interest differentials not only reflects the global nature of the pandemic, but also the stunning decline in long-term global inflation differentials.

\footnotetext{
${ }^{1}$ Rising stability in the core of the global exchange rate system is noted by Ilzetzki, Reinhart and Rogoff (2019), but they do not explore the issue in detail.
} 
FIGURE 1: DECLINING G3 EXCHANGE RATE VOLATILITY
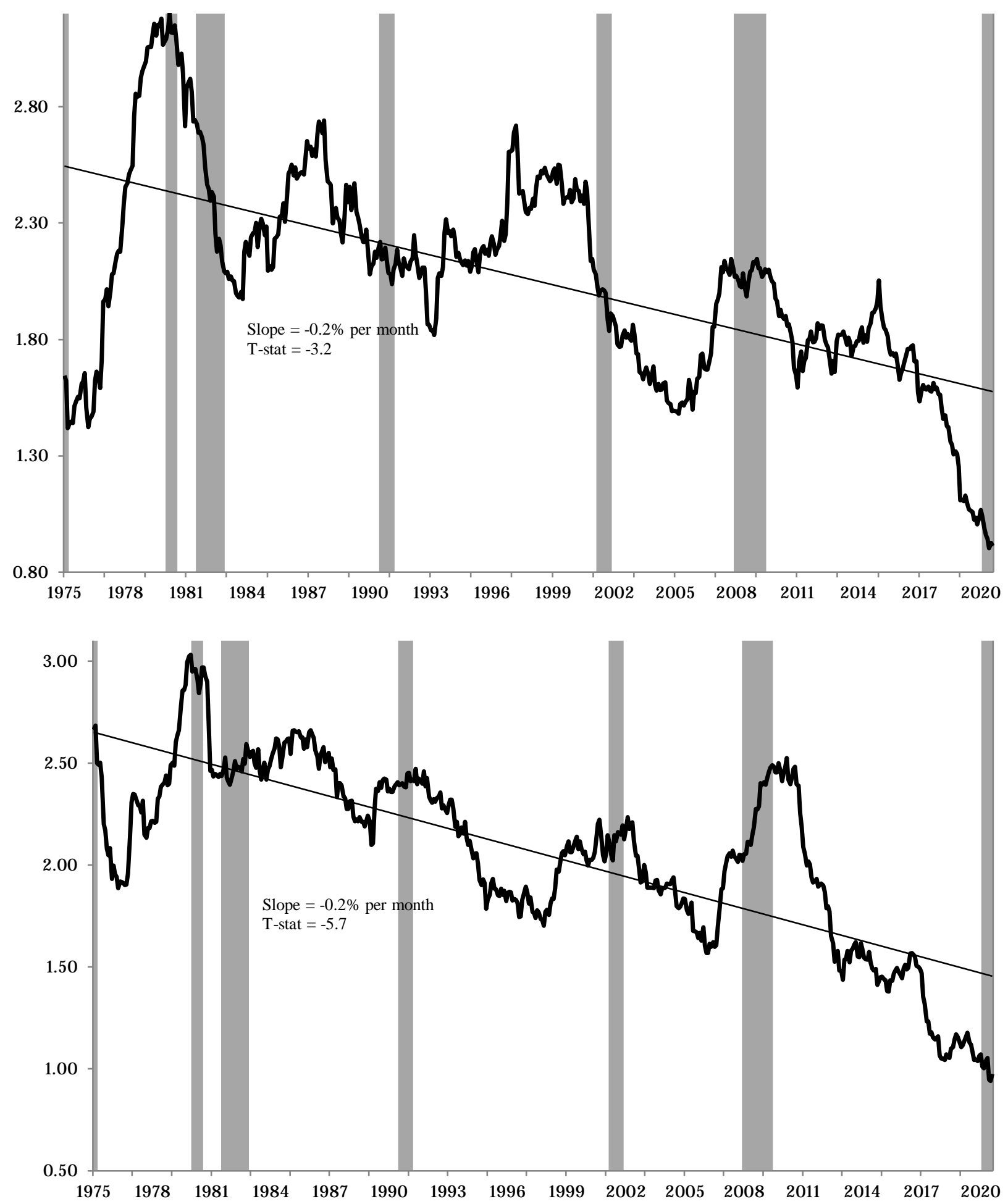

The figure shows the four-year moving average of the absolute value of month on month exchange rate change. Top panel: yen-dollar. Bottom panel: euro-dollar. The euro is replaced with the German Deutschemark before 1999. Shaded areas show US NBER recession dates. Sources: International Finance Statistics, NBER, and the authors. 
We will, of course, consider other possible explanations, including a fall in real or financial risk, massive post-Covid fiscal interventions, and rising dollar dominance including enhanced Fed central bank swap lines. Greater synchronicity of real shocks is also possible. The pandemic has hit the entire world, albeit it has affected some countries much more than others through policy choices and vulnerabilities, with the epicenters moving across time.

For international economists, the "natural experiment” of the Covid shock and its impact on exchange rates has produced interesting and perhaps surprising results. Dornbusch (1976) famously argued that monetary policy uncertainty can, in principle, be a major driver of exchange rate volatility. However, several decades of empirical research, following Meese and Rogoff (1983), has found that supporting this conjecture empirically is difficult. Instead, the literature of the past decade, particularly following the influential work of Gabaix and Maggiori (2015), has argued that risk factors and financial frictions likely play a dominant role; Itskhoki and Mukhin (2019a, 2019b) argue that there is no other plausible way to explain the major puzzles in international macroeconomics. Nevertheless, we argue here that the natural experiment of the Covid-19 shock, which has effectively shut down conventional interest rate policy while exacerbating uncertainty on other dimensions suggests that monetary factors might be more important than previously recognized, not just in the hours following central bank policy announcements, but over much longer horizons as well.

Although emerging market exchange rate volatility is slightly elevated, it remains well below 2008-09 levels, despite the avalanche of challenges and relentless credit agency downgrades. The International Monetary Fund (IMF) has moved proactively to extend credit lines, but its funds are limited, and rallying cries for more aid are largely being lost on advanced countries mired in their own problems. No one believes that EMs are going to have access to the bailout resources that, for example, the Eurozone has extended to southern Europe. After two decades of steady improvements, the risks of a macroeconomic distress and a return to much higher inflation and exchange rate volatility seems greater than at any time since the 1980s.

In Section III, we explore some stark differences between the Covid-19 pandemic and the 2008 financial crisis. The surfeit of liquidity today is certainly one striking feature: In 2008 massive central bank quantitative easing did not have a leveraged effect on broader monetary measures; banks largely held on to reserves without expanding lending. This time is different: Within just a few months, M2 has spiked by 25\% in the United States; monetary aggregates have 
seen a rapid rise globally; corporates have called on lines of credit and borrowing as insurance against a credit squeeze; in the United States, mortgage refinancing is also playing a significant role. There is a liquidity glut.

Lastly, we consider the role of the dollar at the center of the system, a status that most informed observers still view likely to remain extremely durable. However, as Farhi and Maggiori (2017) emphasize, a hegemon's natural temptation to expand debt to very high levels (because it does not fully internalize the risks to rest of the world) can lead to a situation where the "safe" asset is no longer safe, and becomes vulnerable to a loss of confidence. We note that the United States now has as much outstanding public debt in world markets as all of Europe and Japan, with plans to issue much more, even as the US share of global GDP continues its longterm trend decline. Again, the marginal risk/benefit tradeoff may be entirely reasonable from the United States’ perspective, but not necessarily from a global one.

\section{The Secular Decline in G4 Exchange Rate Volatility}

Our tour of the international monetary system in 2020 begins at its core, with the currencies of the largest economic areas by economic activity: the dollar, renminbi, euro and yen, which we label the G4. Together these economies reflect approximately half of world GDP (in purchasing power terms). At their center is the dollar, by far the most traded currency, the currency of choice for central bank reserves, and the top invoicing currency in trade and financial contracts (Rey 2013; Gopinath 2015; Ilzetzki, Reinhart and Rogoff 2017, 2019, 2020; Maggiori, Nieman and Schreger 2020). In this section, we document our central finding: the long-term secular decline in the volatility of core exchange rates, enhanced when-long term interest rates essentially hit zero in late 2014 and early 2015, and continuing through the Covid-19 shock. ${ }^{2}$ To put this recent decline in perspective, note that even during the period of Great Moderation (before 2008), exchange rate volatility remained relatively stable even as many real variables became notably less volatile (Rogoff, 2006).

\footnotetext{
2 Japanese bond yields declined below 50 basis points in October 2014. German and French 10-year bond yields hit 50 basis points in March 2015. They have all since declined to negative territory, in 2016 in Japan and in 2019 in the core Euro countries.
} 
Figure 1 above documents the declining volatility of G3 currencies: the dollar, euro, and yen. The top panel of the figure shows the volatility (four-year moving average of the absolute value of the month-on-month change) of the bilateral yen-dollar exchange rate from 1975 (shortly after the end of the Bretton Woods system of fixed exchange rates) to August 2020. The bottom panel shows the same figure for the euro-dollar exchange rate, where the euro is replaced with the German Deutschemark before 1999. Both figures show similar dynamics. While exchange rate volatility has seen ebbs and flows, a (statistically significant) downward trend is clearly visible in both bilateral exchange rates. The euro-yen cross rate (not shown) has also declined in volatility.

Very recent trends are perhaps even more striking. G3 exchange rate variability has declined sharply and has been well below trend since around 2014. This decline includes the months of March-June 2020 amidst the global uncertainty surrounding the Covid-19 pandemic. The low exchange rate volatility during Covid-19 recession/depression is a remarkable outlier given that exchange rate volatility has been procyclical historically, tending to increase in US recessions. This is evident in the figure, where US NBER recession dates are shaded. ${ }^{3}$

Figure 2 shows that exchange rate stability isn't merely a manifestation of low asset price volatility more broadly. It shows the difference between the absolute value of the monthly change in the euro-dollar (earlier Deutschemark-dollar) exchange rate to the same metric for several other asset prices. ${ }^{4}$ Panel A gives the difference between exchange rate and oil price volatility. Panel B compares exchange rate and commodity price index volatility. Panel C compares exchange rate volatility to (US) stock market volatility, using the S\&P 500 as a stock market index. Indeed, all three panels show that the declining trend in exchange rate volatility is even more pronounced when compared with other assets.

Panel D of Figure 2 puts the recent exchange rate volatility decline in longer historical context. The first two decades shown in the panel, the 1950s and 1960s, are the years of the Bretton Woods system of fixed exchange rates. Not surprisingly, these are years of low exchange rate volatility both in absolute and relative terms. However, the panel highlights that in the past several years, the volatility of exchange rates relative to that of other assets is now low even

\footnotetext{
${ }^{3}$ The question of volatility is separate from what has happened to the level of the exchange rate. There has been some discussion as to whether there was an atypical decline in the dollar during "flight to safety" episodes throughout 2020. Whatever the value of the dollar relative to other major currencies, is variability has been nearly null relative to previous — and far smaller-recessions.

${ }^{4}$ We use difference rather than ratio as our relative metric due to occasional zero and near zero observations.
} 
Figure 2: Declining EUR/USD Exchange Rate Volatility Relative to Asset Prices Panel A: EUR/USD vs. Oil Price Volatility

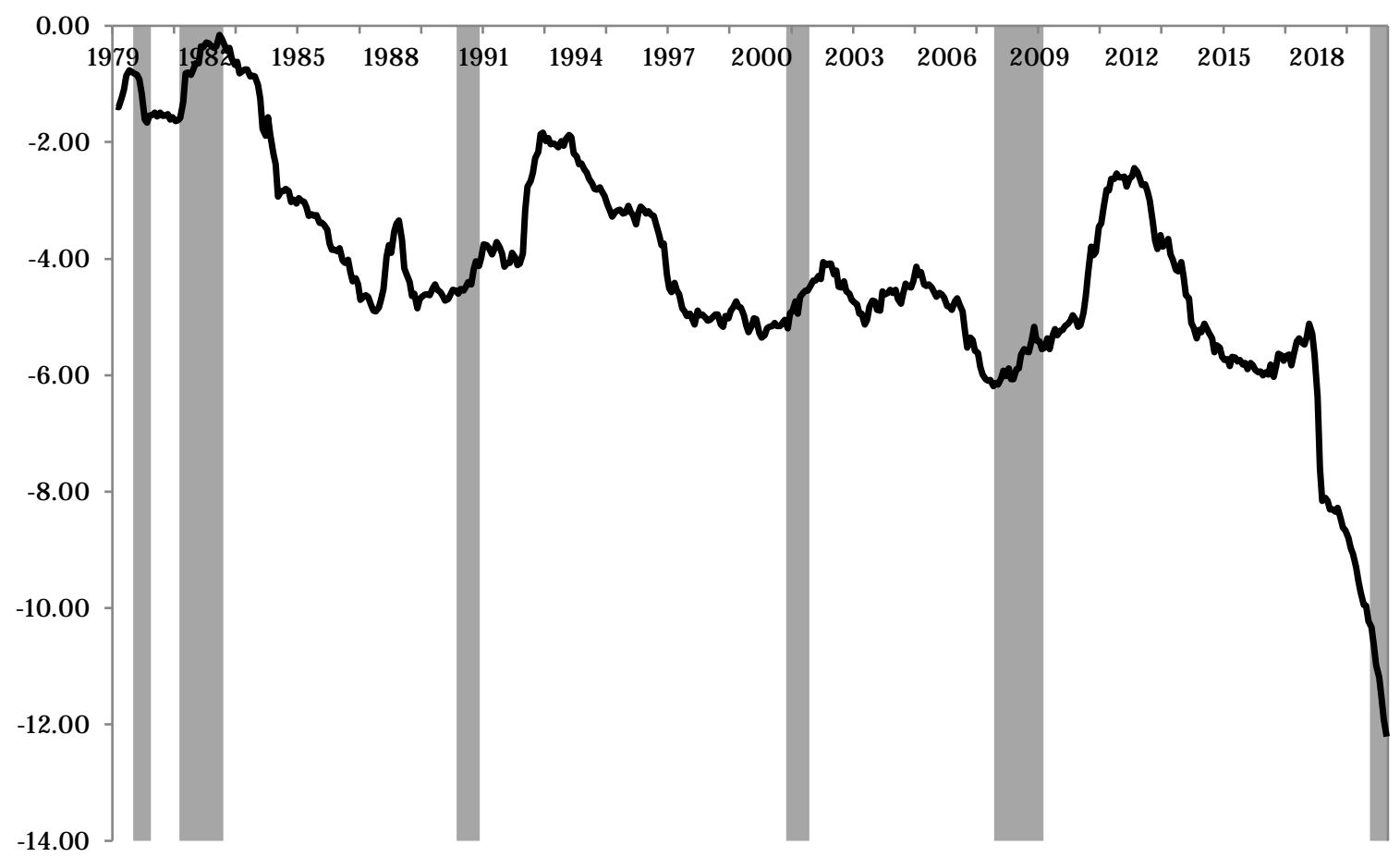

Panel B: EUR/USD vs. Commodity Price Volatility

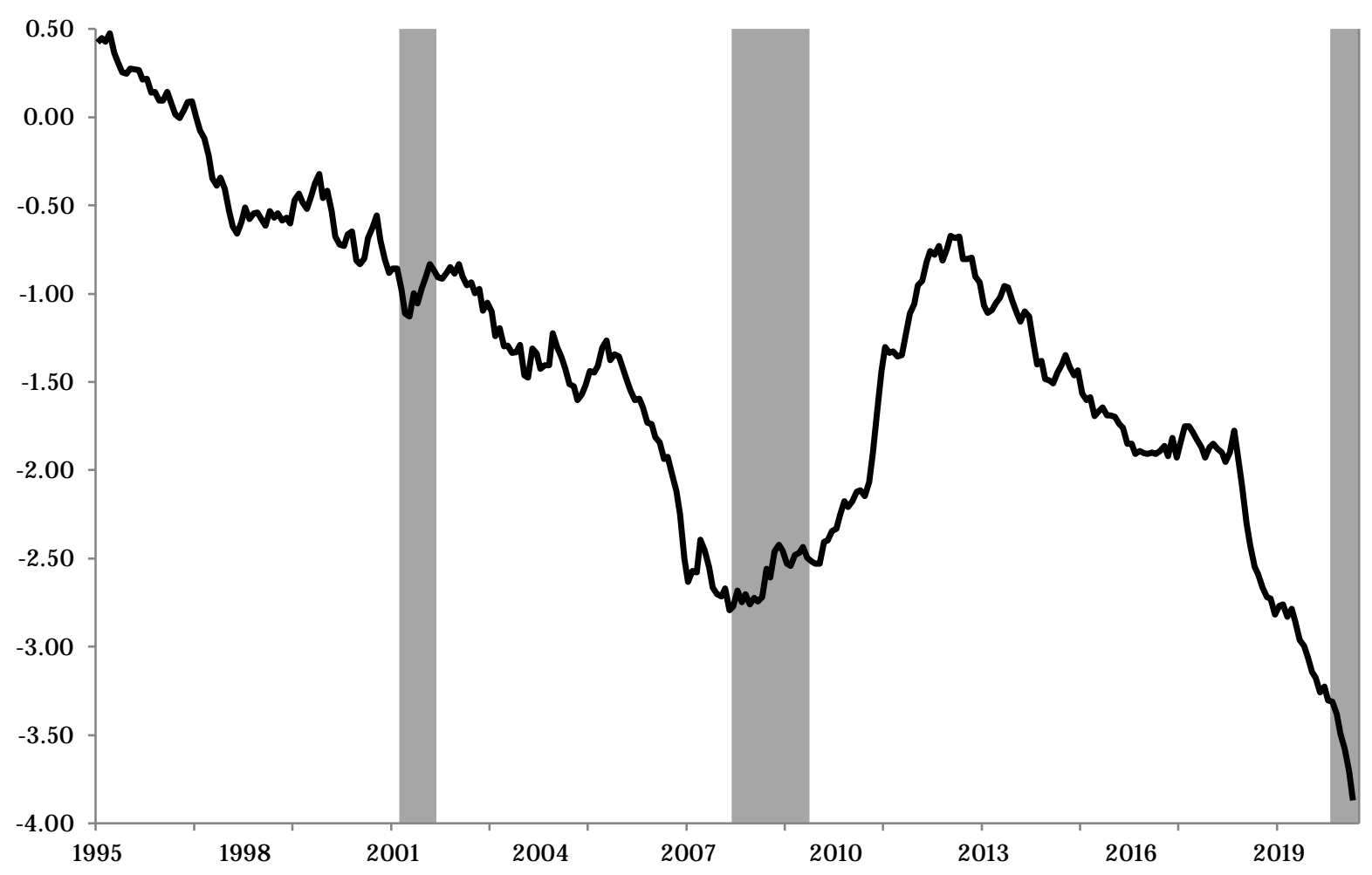


Panel C: EUR/USD vs. Stock Market Volatility, 1975-2020

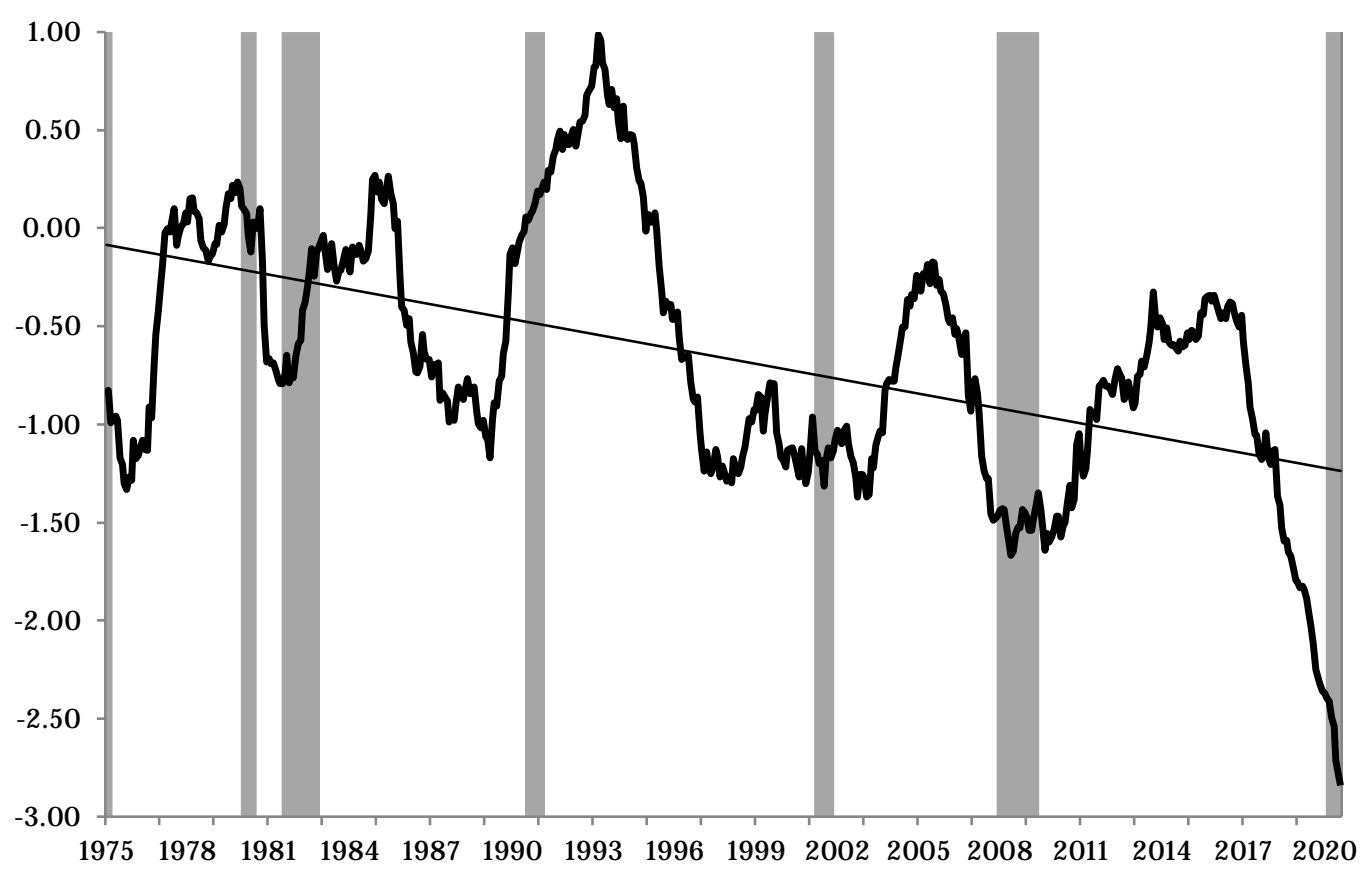

Panel D: EUR/USD vs. Stock Market Volatility, 1950-2020

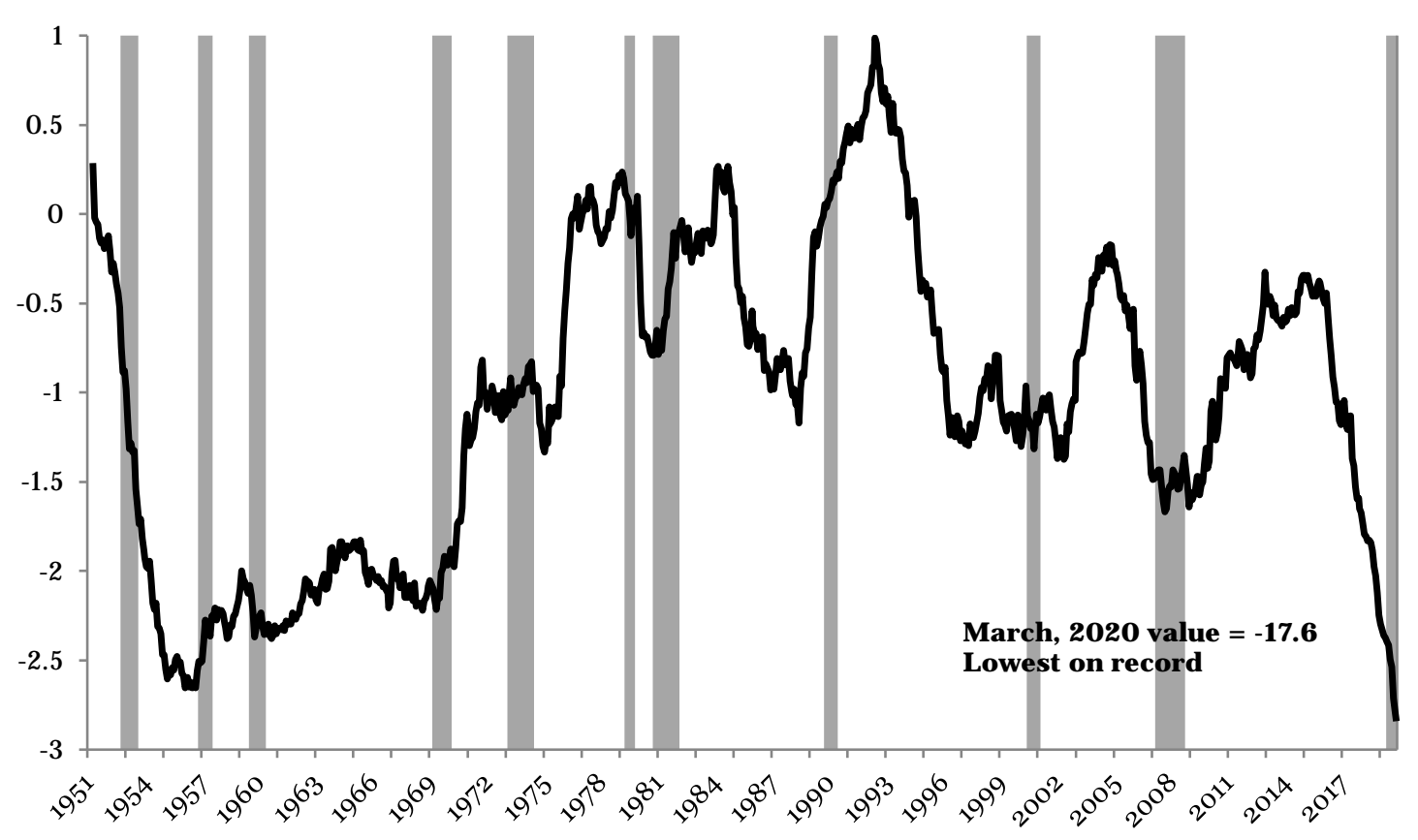

The figure shows the four-year moving average of the difference between the monthly change in the euro-US dollar exchange rate (spliced with the German Deutschemark at 1999) and the absolute value of the monthly change in asset prices. The assets in the four panels are: (A) Oil: spot price of crude West Texas Intermediate (WTI), dollars per barrel; (B) All commodity price index (C) S\&P 500, 1975-2020; (D) S\&P500 1950-2020. Sources: The Federal Reserve Bank of St. Louis, International Finance Statistics, the IMF primary commodities database, Shiller (2005) and the authors. 
compared to Bretton Woods. Relative to the stock market, March 2020 was the month with the lowest exchange rate volatility on record.

While the Chinese renminbi still plays a far less important role in international commerce and finance compared to G3 currencies, China is by some metrics already the largest economy in the world and the renminbi is gradually expanding its international role. ${ }^{5}$ Thus, in comparing the international system under “Extended Bretton Woods II” to earlier episodes, it makes sense to consider the renminbi in a basket of the main "G4 currencies".

Figure A1 in the appendix shows the renminbi’s volatility vis a vis the dollar and the euro. Over the past two decades, China has fixed its exchange rate, first against the dollar and starting in 2015, to a basket. Hence the stability of the renminbi-dollar exchange rate is hardly news. However, the figure demonstrates two less obvious facts. First, as the People's Bank of China moved towards pegging the renminbi to a basket of currencies, the greater volatility in its dollar exchange rate has been replaced roughly one-to-one with declining volatility relative to the euro. Whereas the renminbi has shown slightly more volatility relative to the dollar since 2015, its flexibility relative to the euro and the yen has declined. Second, even prior to 2015, renminbieuro exchange rate variability was on a downward trend because of the declining euro-dollar volatility documented in Figure 1.

Figure A2 in the appendix compares G4 currency volatility during the two decades of Bretton Woods II with the volatility of the top four currencies (the dollar, Deutschemark, UK pound, and French franc) during the original Bretton Woods system from 1950 to 1970. The figure shows that in its prime, Bretton Woods saw far lower (nearly zero) exchange rate variability than core rates during the past two decades. However, the figure also illustrates the relative durability of the current international monetary arrangement. With inflation in Western Europe hitting double digits in the 1950s, and active parallel markets for the exchange of these currencies, the shadow exchange rate among the core countries was still volatile. Indeed, with the United Kingdom devaluing the pound and serving as the largest borrower from the International Monetary Fund (IMF) during these 1950s, it took a full decade before Bretton Woods brought the exchange rate stability originally promised. This success was also short lived. The figure shows that only a

\footnotetext{
${ }^{5}$ As a currency, the renminbi is gradually making inroads as an international currency and some predict that it may have equal status to the dollar within decades (Eichengreen 2011).
} 
decade later, the system was coming apart at its seams. Bretton Woods II has already outlived its namesake in longevity.

Further, the modern G4 comprise 50\% of world GDP (in purchasing power terms, even more at market rates) compared to $40 \%$ for the previous G4 in 1960. It is also useful to recall that the Soviet Union was the second largest economy in the world and was not part of the Bretton Woods arrangement. The current arrangement is thus far more global in its reach than Bretton Woods I. Finally, note the increased exchange rate stability within blocs, as the modern period is characterized by the advent of the euro and the elimination of 19 national currencies in Europe.

Turning to other high-income economies outside the G4, the trends look different in some respects, but similar in others. Figure A3 in the appendix shows the exchange rate volatility of the next 3 main currencies in terms of trading volumes. In contrast to G4 currencies, the Australian and Canadian dollars have gradually moved towards greater exchange rate flexibility. However, similarly to the G4, the past 5 years have shown a dramatic decline in exchange rate variability, with exchange rate volatility well below trend, including during the Covid-19 crisis. ${ }^{6}$ This points to common factors, particularly in the past half-decade, leading to universally low exchange rate variability.

Table 1 shows that the changes that are visually apparent are also statistically significant. It reports results of regressions of all pairs of G3 currencies' weekly absolute change in value against several trends and breakpoints. In most specifications we find a small secular downward trend in exchange rate volatility from 1999 to 2020. In all specifications, we find that this downward trend accelerated more than five-fold since 2014. The 2014 breakpoint corresponds almost precisely to the date when the European Central Bank (ECB) set negative interest rates for the first time and many European long-term bonds started trading at negative yields. ${ }^{7}$ This began the period of unprecedentedly low long-run interest rate volatility and differentials across

\footnotetext{
${ }^{6}$ The exception is the UK pound, where the large depreciation following Brexit and the volatility due to Brexit uncertainty have led to a small increase in exchange rate volatility.

${ }^{7}$ The breakpoint is located at August 2014, where the Bai and Perron (1998) test identifies a statistically significant breakpoint in the trend of the absolute value of change of the dollar exchange rate against a GDP-weighted euro-yen basket. This date follows only shortly the adoption of negative interest rates by the ECB in June 2014. An additional breakpoint is in August 2008, corresponding to the global financial crisis. This breakpoint reflects an increase in trend volatility and most likely reflects a temporary increase in the level of volatility in that period, an impression visually reinforced in Figure 1. Accordingly, we control for the crisis itself, not a change in trend volatility in the crisis. Results are identical when controlling for a break in trend exchange rate volatility in August 2008. Covid-19 wasn’t identified as a formal breakpoint. One is unlikely to capture breakpoints with so few observations at the end of the sample.
} 
TABLE 1: TRENDS AND BREAKPOINTS IN G3/G4 CURRENCY VolATILITY

\begin{tabular}{|c|c|c|c|c|c|c|c|}
\hline & $(1)$ & $(2)$ & $(3)$ & $(4)$ & $(5)$ & $(6)$ & $(7)$ \\
\hline Trend & $-.03 * * *$ & $-.02 * * *$ & -.01 & $-.02 * * *$ & & & \\
\hline Trend after Aug 2014 & & $-.12 * * *$ & $-.17 * * *$ & $-.14 * * *$ & $-.15 * * *$ & $-.15 * * *$ & $-.10 * * *$ \\
\hline $\operatorname{Abs}(\Delta \% \mathrm{~S} \& \mathrm{P} 500)$ & & & $.07 * * *$ & $.05 * * *$ & $.05 * * *$ & $.05 * * *$ & $.04 * * *$ \\
\hline $\operatorname{Abs}(\Delta \%$ Oil Price $)$ & & & $.02 * * *$ & $.01 * * *$ & $.01 * * *$ & $.01 * * *$ & $.01 * * *$ \\
\hline Global Financial Crisis & & & & $.74 * * *$ & $.74 * * *$ & $.74^{* * *}$ & $.56 * * *$ \\
\hline Currency-Pair Fixed Effects & No & No & No & No & Yes & Yes & Yes \\
\hline Currency-Pair specific trends & No & No & No & No & No & Yes & Yes \\
\hline Including China & No & No & No & No & No & No & Yes \\
\hline
\end{tabular}

The table shows results from a panel OLS regression where the dependent variable is the absolute value of the week on week change in G3 exchange rate pairs. Trend is a linear time trend. Trend after August 2014 is an interaction between a linear time trend and a dummy equaling one for weeks after August 2014. This is the date identified as a trend breakpoint in a Bai and Perron (1998) stability test. Coefficients on these two variables are multiplied by 100 to ease reading and reflect the monthly change in the absolute value of exchange rate change in basis points. The regressions show more than a five-fold acceleration in the decline in volatility starting in 2014, with exchange rate volatility declining at a rate of close to 10 basis points per year from an average of 75 basis points. A constant and a dummy for weeks after August 2014 were included but not reported. Abs $(\Delta \%$ S\&P500) and Abs( $\Delta \%$ Commodity Prices) are the absolute values of the weekly percentage growth in the S\&P500 stock market index and crude West Texas Intermediate (WTI) oil prices. Columns 1-6 are regressions for G3 currency pairs. Column 7 also includes cross rates with the renminbi. Columns 5-7 include currency pair fixed effects. Columns 6-7 also include separate time trends for each currency pair. 
countries, as we discuss in the following section. The table also shows that the trend since 2014 is even more pronounced when controlling for volatility in other asset prices, confirming the visual impression from Figure 2. Allowing for an additional break in exchange rate volatility during the Covid-19 pandemic generally shows a further acceleration in the decline in exchange rate volatility, but the result is not yet statistically significant in most specifications, as could be expected due to the short time frame.

\section{Exchange Rate Stability and Monetary Developments}

What explains the declining G4 exchange rate variance and their surprisingly muted responses to the massive shocks of Covid-19? Only a single country (China) we analyzed in the previous section has an explicit policy of targeting its exchange rate. While others may have less flexible exchange rate regimes de facto (Ilzetzki, Reinhart, and Rogoff 2019) there is no sign of a conscious move to greater exchange rate management among the central banks in question, certainly not from central bank statements. Instead, we conjecture that inflation, growth, and interest rate trends, culminating in the low inflation environment and the zero-lower bound on monetary policy of the past decade, have led to low exchange rate volatility. ${ }^{8}$ In this section, we provide suggestive evidence that monetary convergence to the zero bound has been especially important. We then turn to other, less likely (in our view), explanations for the volatility decline.

\section{II.A Inflation and Interest Rate Dynamics}

Over the past decade, global inflation has been remarkably muted. Several major economies have flirted with deflation; inflation-targeting central banks faced the unusual challenge of attempting to hit their targets from below. With inflation in single digits virtually everywhere in the world, inflation differentials across countries have also declined. Purchasing power parity requires that exchange rates adjust to cross-country price differences in the long run. Hence low inflation differentials may lead to smaller contemporaneous and expected trend exchange rate adjustments.

\section{FIGURE 3: DECLINING INFLATION VOLATILITY}

\footnotetext{
${ }^{8}$ In an important related paper, Stavrakeva and Tang (2020) use surveys and data on macro news to decompose factors driving exchange rates. Their decomposition supports the view that the effects of monetary policy factors on exchange rate volatility has been diminishing over time for most exchange rate pairs.
} 
Panel A: Average and Standard Deviation of Annual Inflation, 22 Advanced Economies

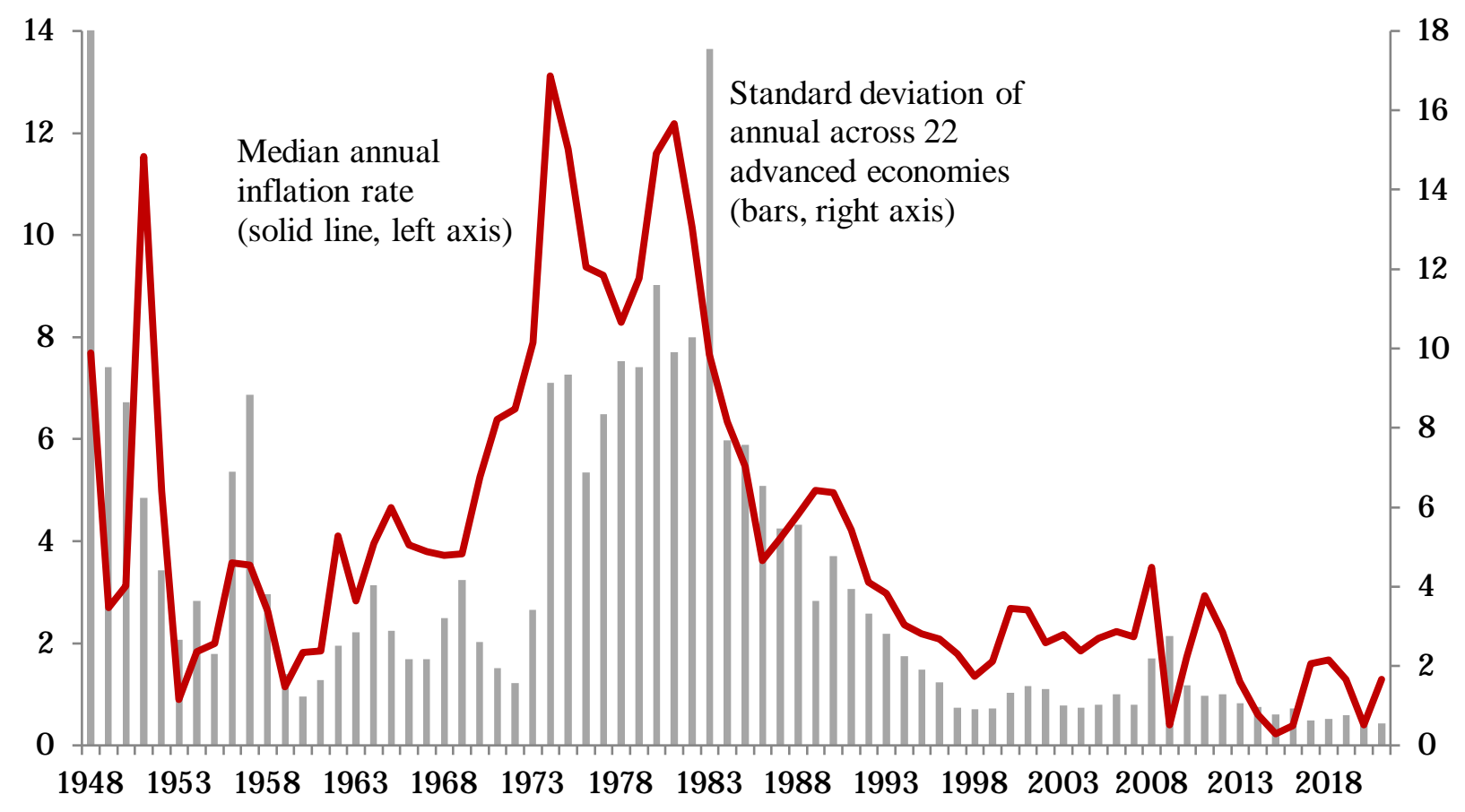

Panel B: Share of Countries with Low (<2.5\%) and Negative Inflation

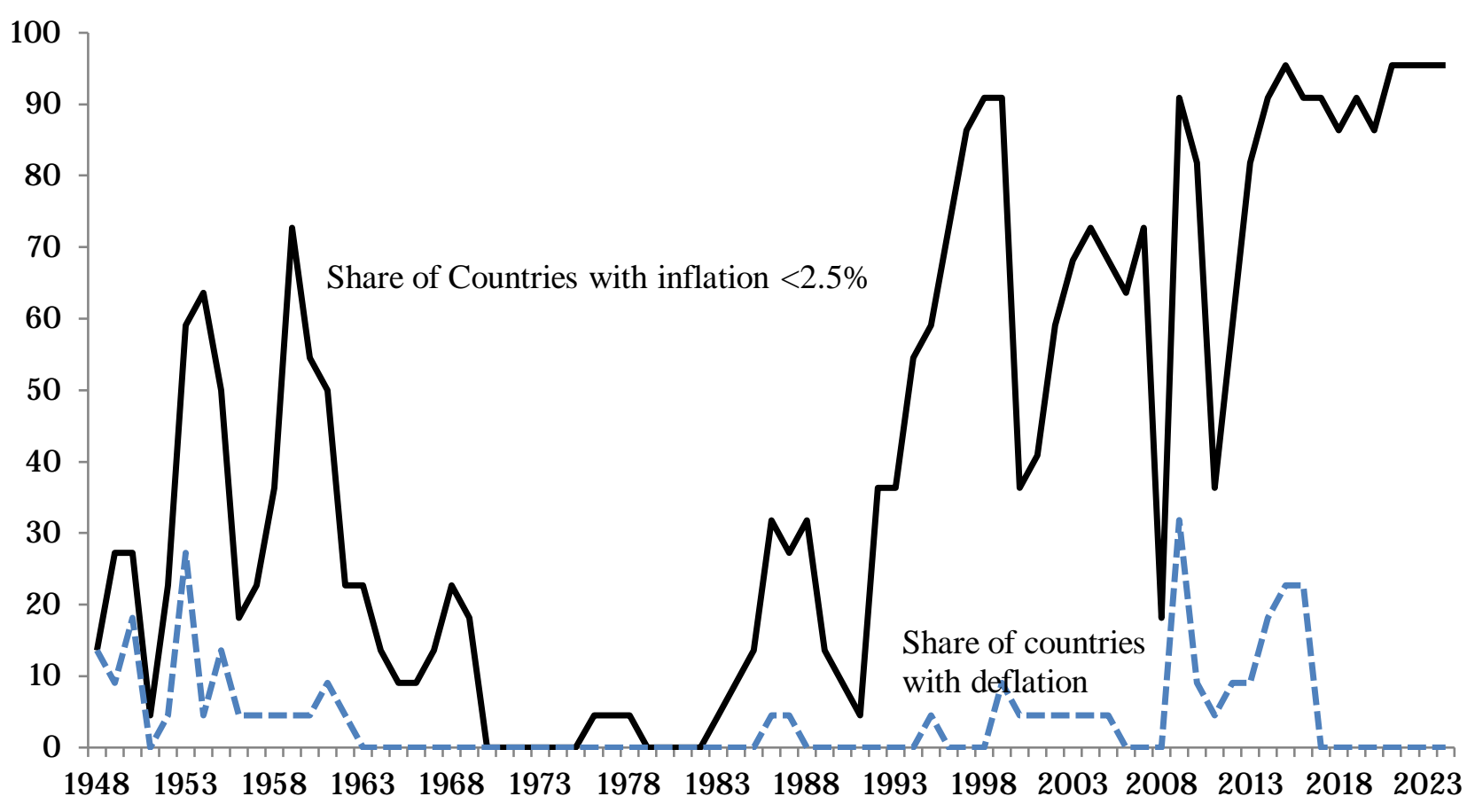

Sources: IMF World Economic Outlook (including projections) and the authors. 
Panel A of Figure 3 shows the standard deviation of annual inflation rates across 22 advanced economies (in bars) and the average inflation rate (in a line) from World War II to today. More pertinent for exchange rate determination is that cross-country inflation differentials have also declined. The past two decades have witnessed the lowest differentials in inflation across countries on record in the post-war period. The figure extends to the year 2030, replacing actual inflation variation with variation in inflation projections across countries, using the April 2020 IMF World Economic Outlook. The differentials are projected to continue to shrink.

Panel B of Figure 3 shows that the share of high-income countries with annual inflation below $2 \frac{1}{2}$ percent (solid line) is now hovering near $100 \%$, a feat never achieved in the Bretton Woods years. The dashed line shows the share of countries in deflation. The deflationary episodes experienced by many countries following the global financial crisis (GFC) have subsided, so that today nearly all high-income economies have inflation rates in the narrow 0 to 21/2 percent band. Of course, purchasing power parity holds only weakly in the data and often requires many years to unfold (Rogoff 1996, and Gopinath and others 2020). As such, inflation differentials can only be part of the story in explaining the decline in exchange rate variability, particularly at higher frequencies. Even more important, albeit related, is the convergence of short-term and long-term interest rates.

Panel A of Figure 4 shows the standard deviation of the monetary policy interest rate of the central banks issuing the ten most traded currencies in 2020 (solid line), going back to 2000. The secular decline in the level of global interest rates is well documented, but as the figure emphasizes, this has been associated with smaller variation in policy rates across countries as well. The dashed line in the figure shows the percent of countries with zero or negative interest rates (defined as 25 basis points or below, as some central banks were reluctant to set rates exactly at zero). ${ }^{9}$

\footnotetext{
${ }^{9}$ Interestingly, Lilley and Rinaldi (2020) find after the financial crisis, exchange rates for riskier advanced economy currencies (which would have included the euro during the euro crisis) became more correlated with measures of global market risk (e.g, the VIX), possibly because during the zero bound constraint implied that central banks had less room to allow policy rates to move to offset changes in global risk, so exchange rates absorbed more of the adjustment.
} 
Figure 4: DECLINING Policy InTERest RAte Volatility

Panel A: Standard Deviation Monetary Policy Rate and Share at the Zero Lower Bound.

10 Major Currencies, 2000-2020

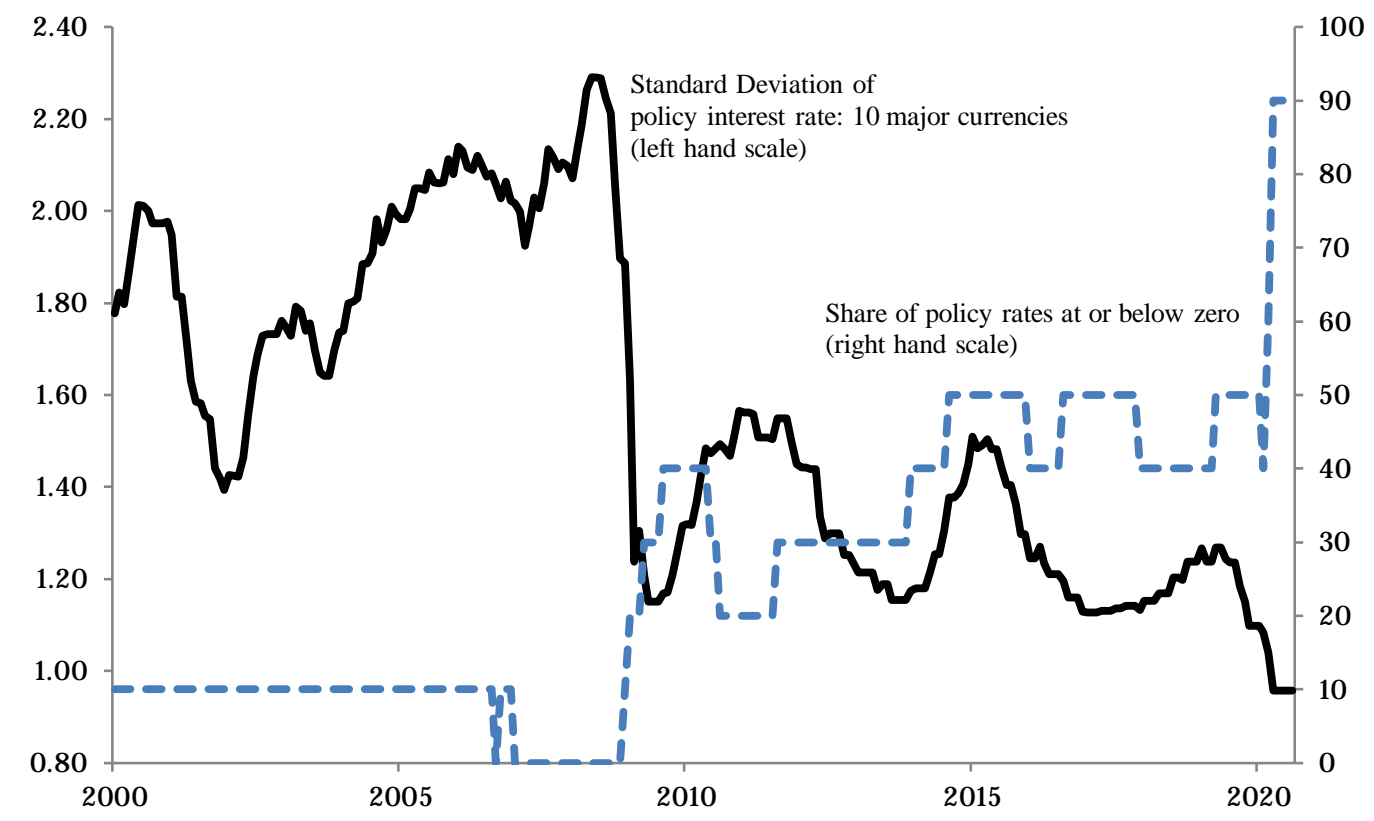

Panel B: Average and Standard Deviation Monetary Policy Rate

US, Germany, UK and Japan, 1959-2020

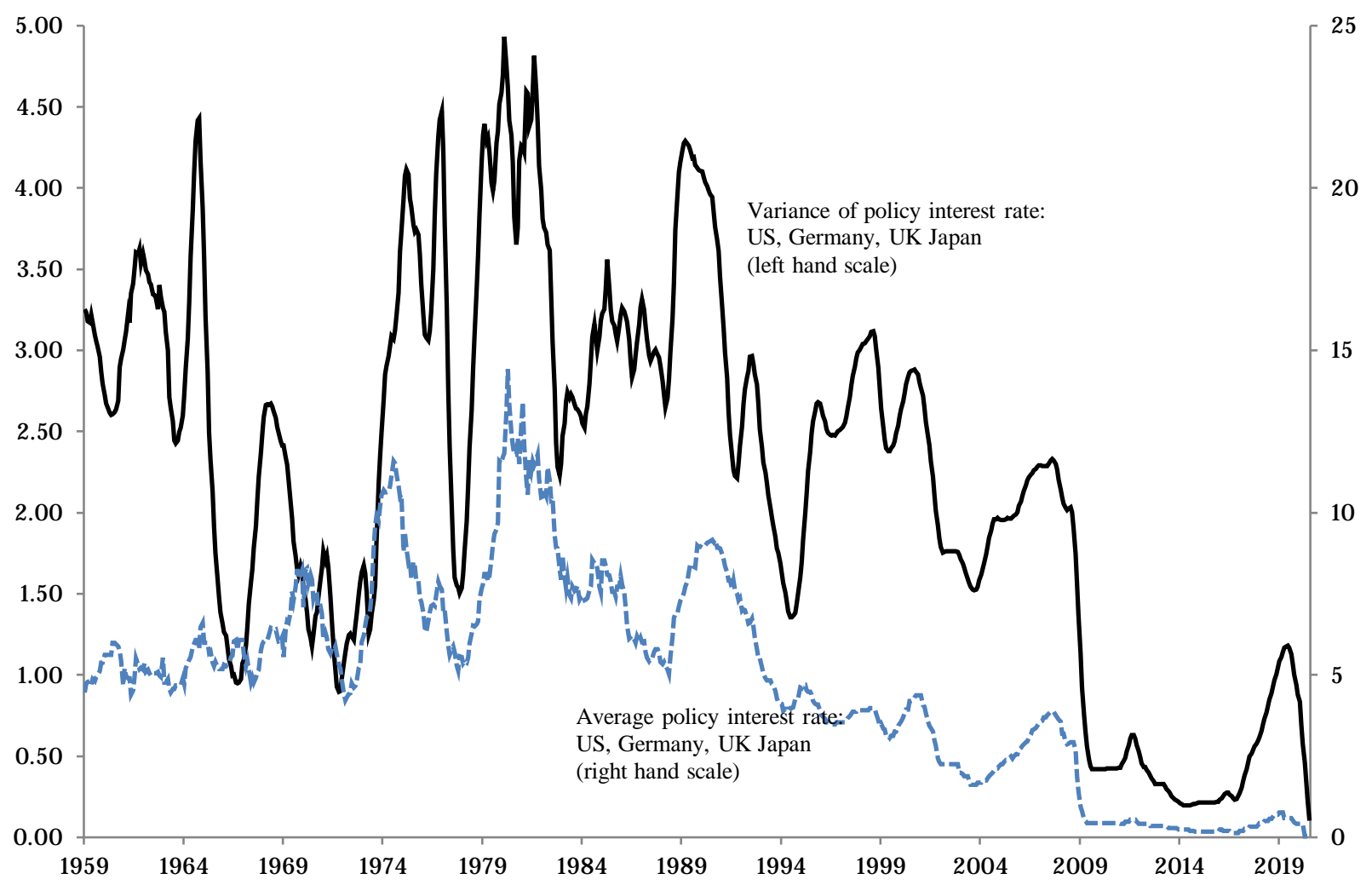

Sources: IMF, International Finance Statistics, national central banks, and the authors. 
At the beginning of the sample only Japan had zero interest rates. By 2020, all but one of the central banks considered here (the People's Bank of China) had interest rates at zero or below. With policy interest rates stuck at zero, and shadow policy rates (estimated by say, a Taylor rule) expected to remain well below zero for years to come, the scope for short-term interest rate differentials is minimal. (We recognize that we are abstracting from risk premia that can create a wedge between interest differentials and expected exchange rate movements, but these are small compared to the generalized collapse in interest rates.)

Panel B of the figure puts recent trends in a longer historical perspective going back to 1959, restricting attention to four major central banks (the Federal Reserve, Bundesbank/ECB, Bank of Japan, and the Bank of England). The figure shows that as average monetary policy rates have declined (dashed line), the variance among them has also declined. What little variance remains is mainly because some central banks have opted for negative rates while others have so far treated zero as the lower bound on the nominal policy rate. Interestingly, variation in policy rates across countries has been more stable in the second decade of the 21st century than it was under Bretton Woods I, where monetary policy coordination should have been a consequence of the fixed exchange rate system, at least once controls on international capital movements were lifted. With central banks setting policy interest rates to zero and expected to pursue these policies for years to come (because of economic conditions regardless of the credibility of forward guidance) the degree of de facto monetary coordination has never been greater.

Indeed, the collapse of long-term interest rate differentials, illustrated in Figure 5, is a key element of the story; standard monetary models of exchange rates suggest that the entire term structure of interest differentials matters. ${ }^{10}{ }^{11}$ Figure 5 illustrates how the distribution of the annual interest rate on 10-year bond yields for 22 high-income economies has evolved throughout the post-war period (top panel: nominal, bottom panel: real). The stable years of the Bretton Woods period (1954-1969) are shown in a solid black line, with 10-year bond yields averaging $6 \%$ and an average annual cross-country variance of $2.2 \% .{ }^{12}$ The demise of Bretton

\footnotetext{
${ }^{10}$ In addition, uncovered interest parity (UIP), relating interest rate differentials to exchange rate dynamics, holds better empirically with longer term rates.

11 The decline in interest rate variance is in part a mechanical implication of the decline in the level of interest rates. However, according to UIP theory, exchange rate volatility is determined by the volatility of interest rates differentials, even if the latter declined due to this mechanical artefact.

12 We exclude Greece from the sample as its high bond yields dominate the mean and variance in the 1950s and 2000s.
} 


\section{FIGURE 5: 10-YEAR BOND YIELDS FOR 21 HIGH INCOME ECONOMIES}

Panel A: Nominal Yields

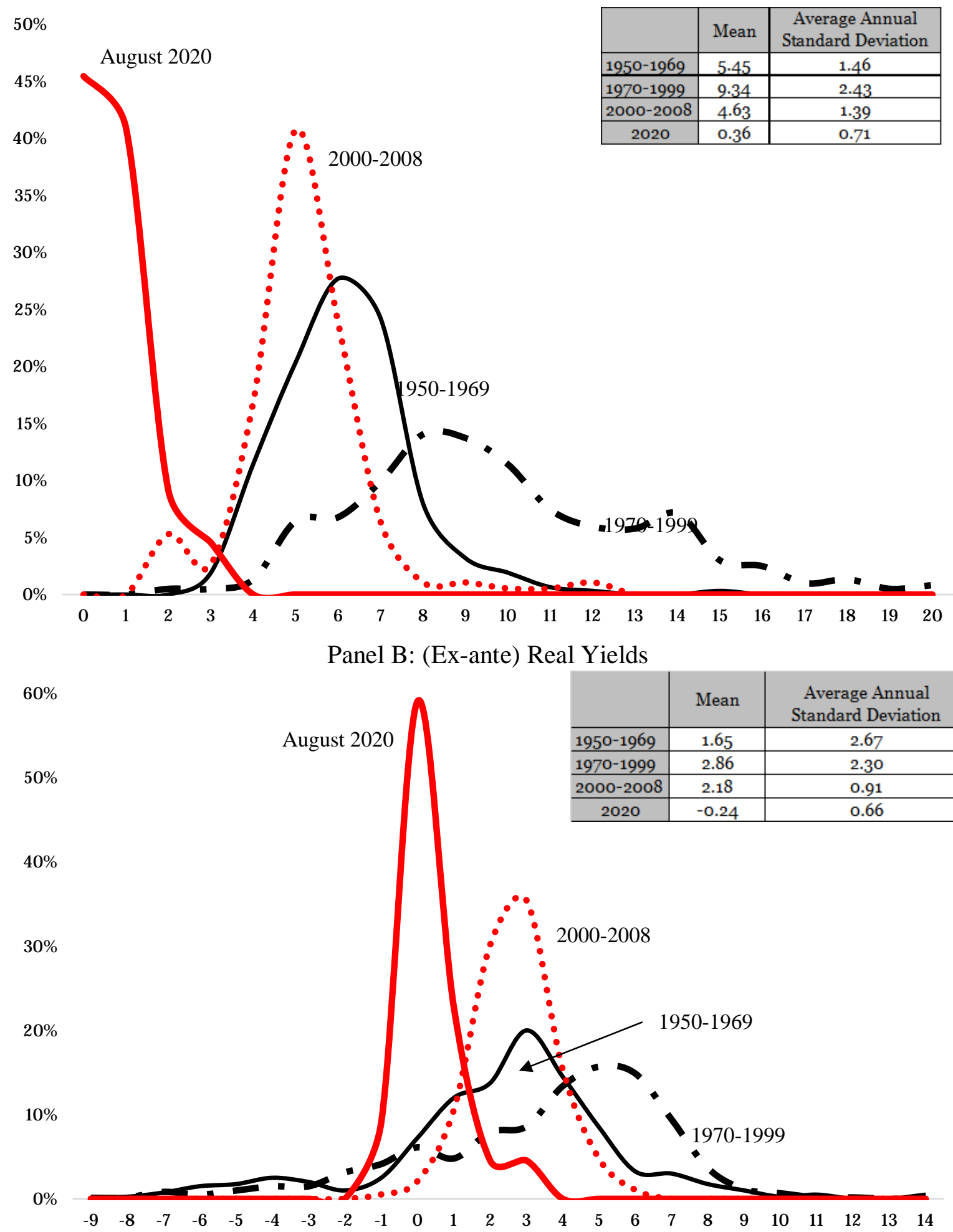

Sources: IMF, International Finance Statistics, World Economic Outlook, and the authors. Ex-ante yields calculated based on inflation in the preceding year. 
Woods and the high inflation of the 1970s brought a period of higher yields (averaging 9\%) and a dramatic increase in interest rate variability (an average annual variance of 6.6\%) in 19701999, (shown in a dashed black line). Long-term interest rate differentials across countries have declined in the $21^{\text {st }}$ century, returning to the variance the Bretton Woods period (averaging $5 \%$ and with an average annual variance of $2.1 \%$, shown in a dashed red line.) The $21^{\text {st }}$ century variance is even lower at $1.85 \%$ when removing the single year of 2011, when spreads increased during the Eurozone crisis. Finally, the solid red line shows the distribution of long-term interest rates in early August 2020. ${ }^{13}$ The decline in long term interest rates is unprecedented in the modern era; nearly half of the high-income economies are borrowing at negative nominal rates at 10 -year horizons. The variance across countries is also at historical lows $(0.5 \%)$. The bottom panel of the figure shows a similar decline in real long-term rates.

Although non-monetary explanations are possible—and we will consider them-the collapse of exchange rate variability is certainly consistent with the exchange rate overshooting model of Dornbusch (1976), which placed monetary policy volatility front and center.

\section{II.B Alternative Explanations for Exchange Rate Volatility}

If not convergence of monetary policy, what other factors might explain the fall in exchange rate volatility?

\section{THE DOLLAR'S RISE AS AN ANCHOR CURRENCY}

One plausible argument for greater exchange rate stability is that the dollar has cemented its role as the dominant currency, providing greater incentives for foreign central banks to stabilize their dollar exchange rates, leading to a decline in volatility across the system. Rey (2013) and Gopinath (2014) have emphasized the dominant role of the dollar; we review the evidence in Ilzetzki, Reinhart and Rogoff (2019), and discuss why the euro has fallen so far short as a challenger in Ilzetzki, Reinhart and Rogoff (2020).

Dollar dominance is a plausible explanation, but by most measures it has been relatively stable for the past decade and cannot easily explain the sharp drop in volatility after Covid-19. If anything, thanks to a dramatic introduction of Eurobonds to cushion the most hard-hit European

\footnotetext{
${ }^{13}$ Each line in Figure 5 shows a distribution of interest rates over time windows of different length. The distributions in the longer time periods are mechanically fatter because each reflects within country variance over time in addition to within country variance. The tables in the figure show the average annual variance in each period, which is more comparable as it only includes variation across countries.
} 
countries, the pandemic has given renewed strength to the euro as an alternative to the dollar over the next decade. We acknowledge that starting in the 2008 and again in 2020, the Federal Reserve engaged in very pro-active measures to stabilize international markets by offering dollar swap lines to advanced-economy central banks and some emerging markets. Had the Fed not acted, there would almost certainly have been a crisis in overseas dollar funding markets, and the potential effects on exchange rate volatility could have been immense. In the future evolution of the global financial system, historians may regard the two crises as marking the evolution of the Fed towards taking a more international role.

The Fed's extension of swap lines is an intriguing alternative hypothesis, but on balance we are skeptical that it can explain the collapse of exchange rate volatility, going far beyond what might be expected if the Fed were simply offsetting a liquidity crunch. Nearly $90 \%$ of outstanding Fed swap lines were indeed to the ECB and the Bank of Japan and it is certainly possible that they cushioned exchange rate volatility. However, Covid-19 central bank swap lines never reached the magnitudes of those in the GFC. Further, by now the ECB has almost entirely drawn down its swap line balances and the Bank of Japan is has unwound three quarters of its holdings. Finally, the decline in exchange rate volatility began accelerating in 2014, well after the previous round of swap arrangements ended and well before the Covid-19 swap lines were in place.

\section{A GENERALIZED DECLINE IN FINANCIAL RISKS}

As we have noted, the academic literature of the past decade has placed an increased emphasis on shifting risk premia and financial frictions as the major driver of short-term exchange rate volatility. Itskhoki and Mukhin (2019) argue that only shifting risk premia can simultaneously explain the Meese-Rogoff disconnect puzzle, the PPP puzzle, the terms-of-trade puzzle, the Backus-Smith puzzle, and the UIP puzzle. It is plausible that the paralysis caused by the zero lower bound actually reduces financial risk; Miranda-Agrippino and Rey (2020) argue that shocks to US monetary policy are major drivers of global risk cycles. More work is necessary to discriminate the risk hypothesis from the Dornbusch model (and new open economy descendants as in Obstfeld and Rogoff, 1996). 
FigURE 6: IMPLIED VOLATILITY: VIX AND CVIX

Panel A: VIX Index 1885-2020

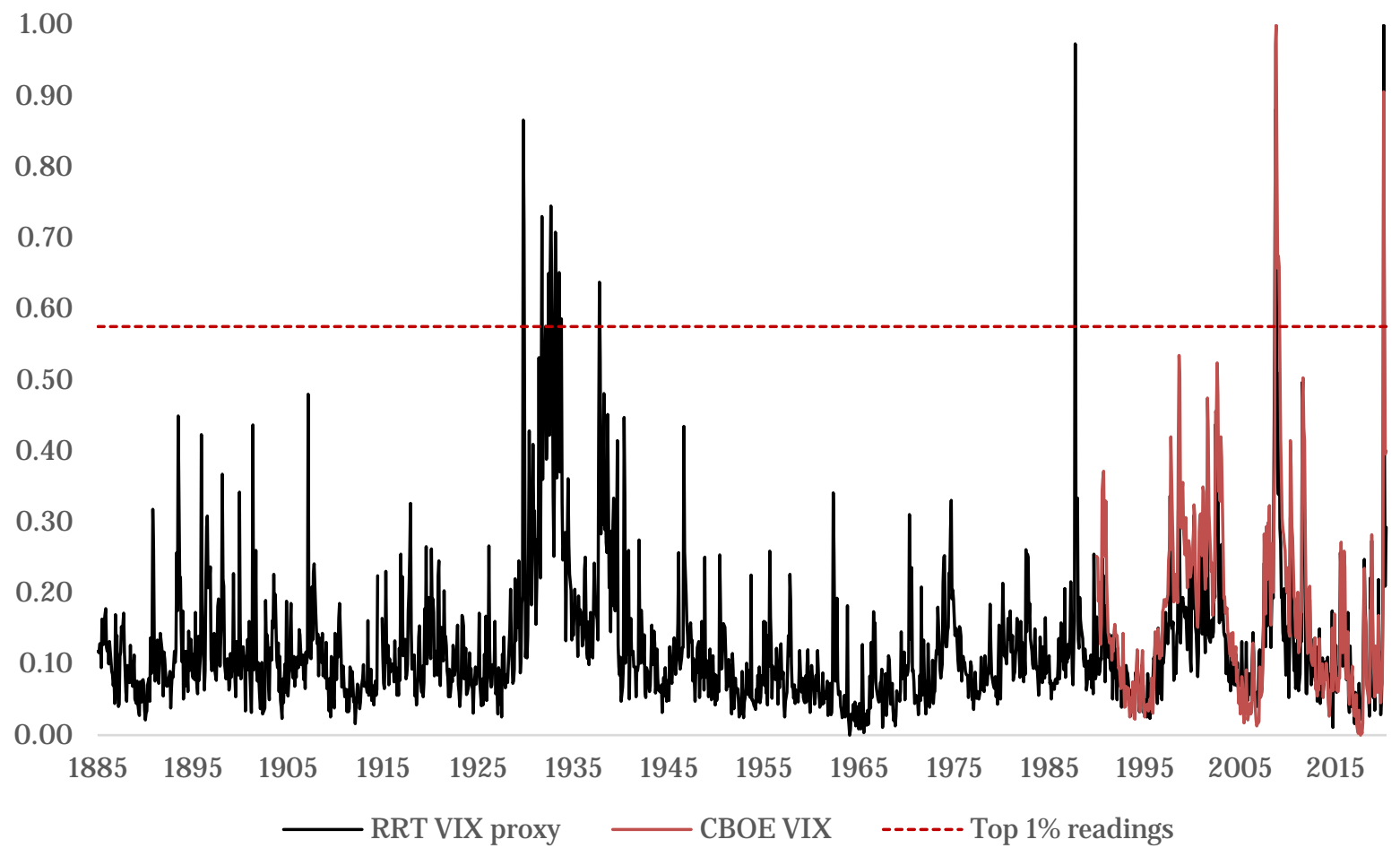

Panel B: VIX (top line) and CVIX (bottom line) 2001-2020

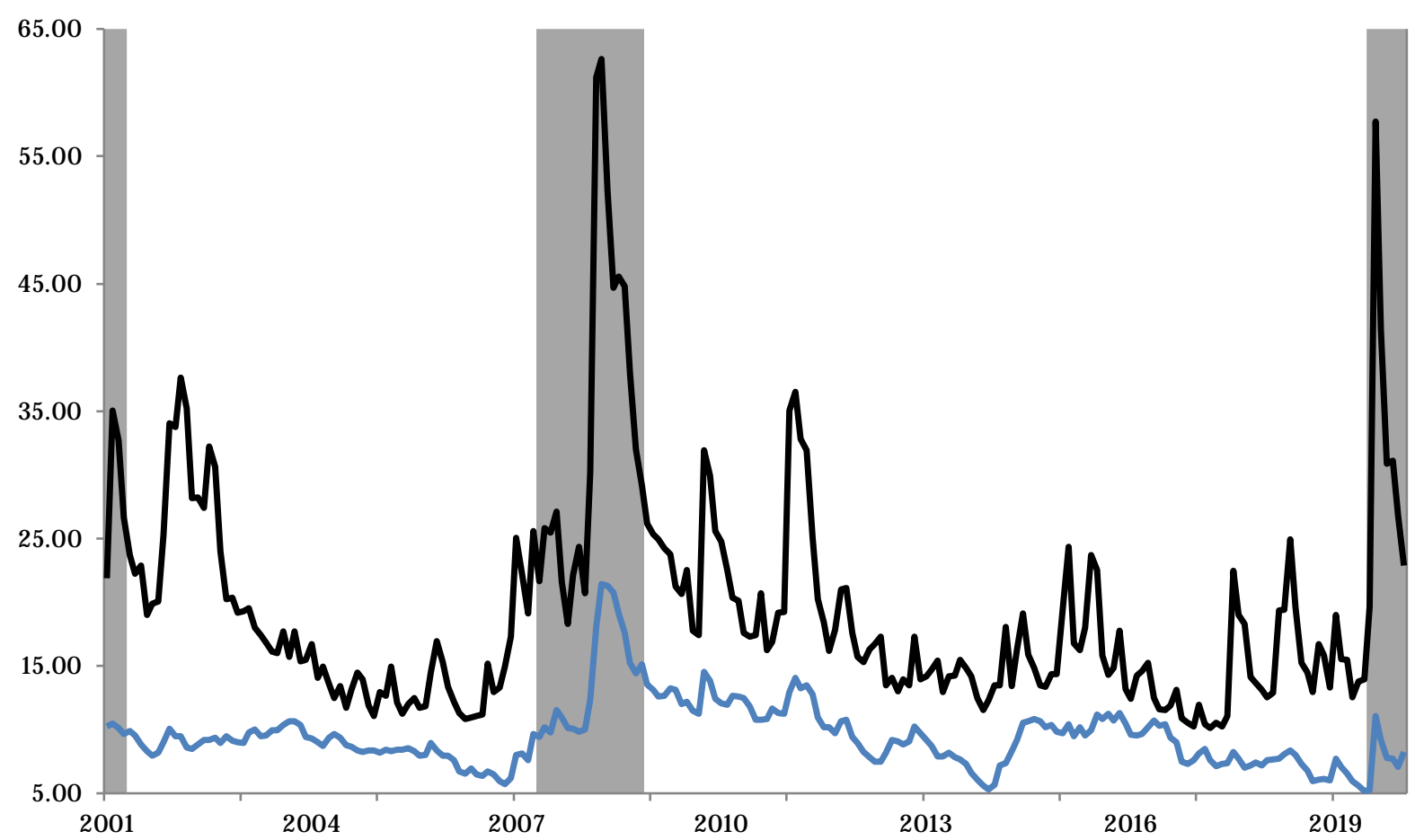

Sources: Schwert (1990), Thompson Reuters, Deutsche Bank, Chicago Board Options Exchange and the authors. 
Nevertheless, the notion that the secular stabilization in 21st century exchange rates came because the world has become a safer place flies against casual observation. The brief paxAmericana of the 1990s was shattered with a major terrorist attack on US soil in 2001 and led the US to two major international conflicts in a single decade. The past twelve years have seen the greatest global financial crisis since the Great Depression and the most consequential pandemic in a century at least. The two crises combined have produced enormous political ferment and uncertainty about the role of the state and the uses of government debt. In the second quarter of this year, the US economy saw its greatest quarterly GDP decline since modern national accounts data have been collected. Measures of financial uncertainty (such as the VIX) remain elevated, even if they have fallen since their huge rise in March. At the same time, exchange rate volatility has declined. The top panel of Figure 6 expands the analysis of Figure 2, illustrating the decline in exchange rate volatility relative to other assets. It shows the VIX index, extended back over a century. The actual VIX index measures “implied volatility”, i.e. private sector perceptions of risk implied from 30-day future options. We extend the series historically using realized volatility, but the two series are highly correlated (89\%) for overlapping months.

The figure shows that the 21st century has been a volatile period for financial markets in historical comparison. The dashed horizontal line in the figure demarks observations that were in the top $1 \%$ of observations in the 135-year time series. Outside the Great Depression, only three other events have shown volatility of these magnitudes: Black Monday in 1987, the GFC in 2008, and the Covid-19 shock of March 2020. Thus, the two decades of declining exchange rate volatility have occurred against the backdrop of two of the greatest episodes of implied stock market volatility in over a century.

Panel B of Figure 6 focuses in on recent years and shows the VIX index (top line) alongside a currency equivalent of the VIX, the CVIX (bottom line), constructed by Deutsche Bank. The CVIX averages the implied volatility of the top 9 currency cross pairs in terms of trade volume. The CVIX has trended slightly downwards: it hit its lowest reading on record in January 2020. The downward trend in the CIVX is moderated compared to our core currency comparisons because it includes not only the G3 currencies of the dollar, euro, and yen (and excludes the renminbi), but also the British pound, Swiss franc, and Australian and Canadian dollars.

While the two series are certainly correlated, the CVIX has shown very different dynamics than the VIX during the Covid-19 pandemic. While the VIX index hit near historic highs in 
2020, the CVIX was below its historical average for all but the single month of March. In March, it hit a value of 11, a figure only half a standard deviation above the index's historical mean, and a value previously exceeded in the unremarkable month of February 2016. The VIX, on the other hand, has come down precipitously since March but remains well above its historical median.

The evidence compiled in Figures 2 and 6 indicate a decline in currency volatility relative to other assets, indicating that a benign risk environment is an unlikely explanation for the phenomenon.

\section{THE REAL ECONOMY AND FISCAL POLICY}

We have already made the point that the trend decline in global exchange rate volatility, particularly at the core, has survived the worst global financial crisis in eight decades and the worst pandemic in a century. Although one can speak of a great moderation in the runup to the 2008 GFC, and a second moderation in the runup to the Covid-19 shock, any measure that takes into account the two crises will show extremely high volatility in output, unemployment, global trade, etc. The argument that exchange rate volatility has fallen because the real economy has become more stable seems highly dubious.

Similarly, it is difficult to reconcile the collapse in exchange rate volatility with recent fiscal activism, either in the runup to Covid-19 or during the pandemic. For example, although the general direction of travel was similar across countries in the pandemic, the timing and magnitudes of fiscal announcements were quite varied across countries, and the exchange rate effects apparently minimal.

Having said this, the global nature of the crisis has itself led to a very coordinated response in central banks across the world. The nature of the shock may therefore have an indirect role in explaining the muted exchange rate volatility that followed. Further, there is far greater coherence across central banks in their expected responses to real shocks and inflation, which may have led to clearer market expectations on monetary policy going forward.

\section{EMERGING MARKETS}

So far, we have mainly focused on advanced economies, we next turn to emerging markets. The greater exchange rate and inflation stability of the 21st century didn't bypass emerging markets. With some notable recent exceptions (Argentina, Ukraine, Venezuela), emerging markets (EMs) have seen low and stable inflation rates and the longest period in the post-war era without a single case of hyperinflation (2003-2013) in emerging markets (Zimbabwe had a 
Panel A: Share of Countries in Currency Crash

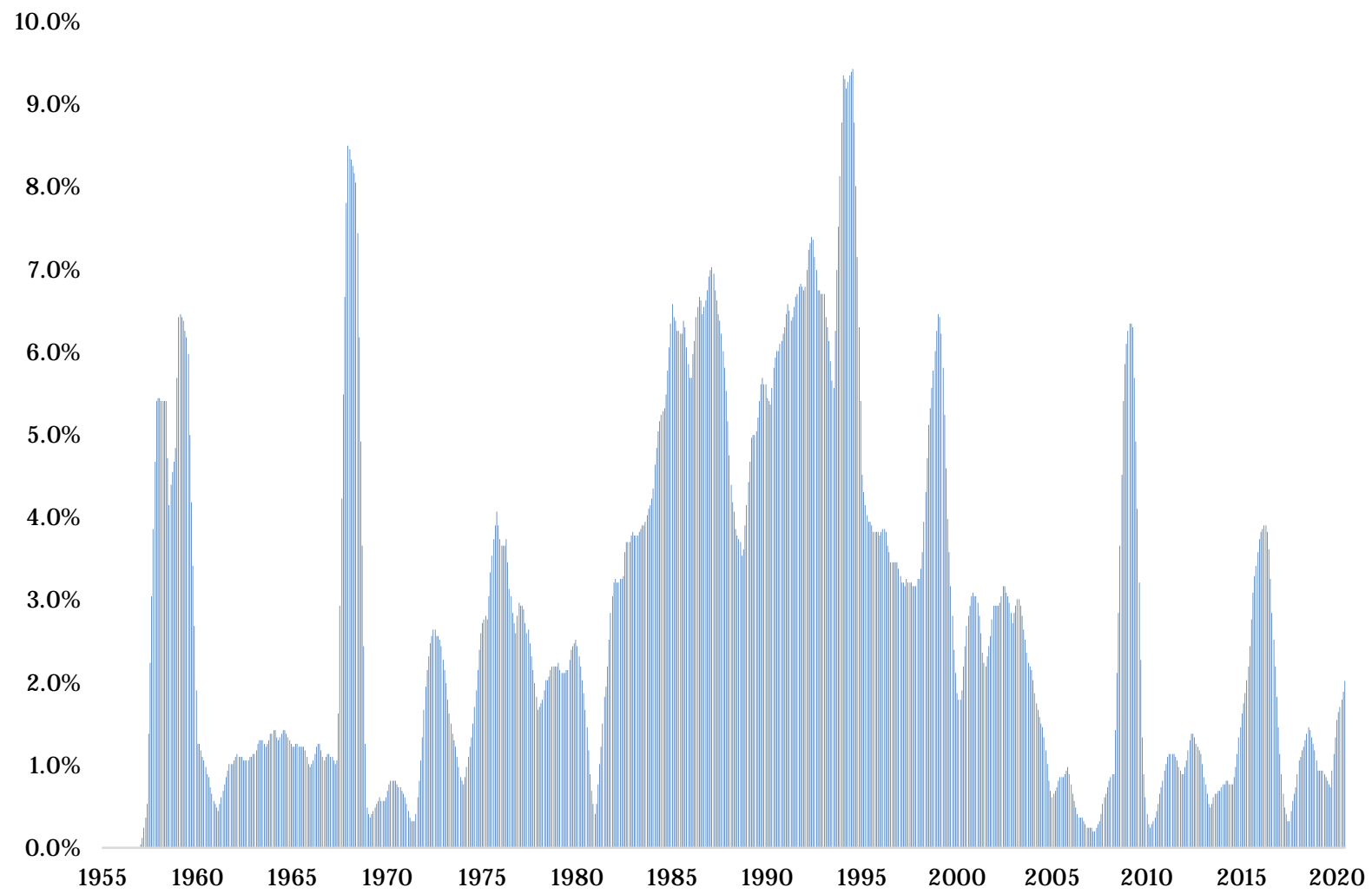

Panel B: Median Emerging Market Inflation \& Share of Emerging Markets w/ Hyperinflation $30 \%$

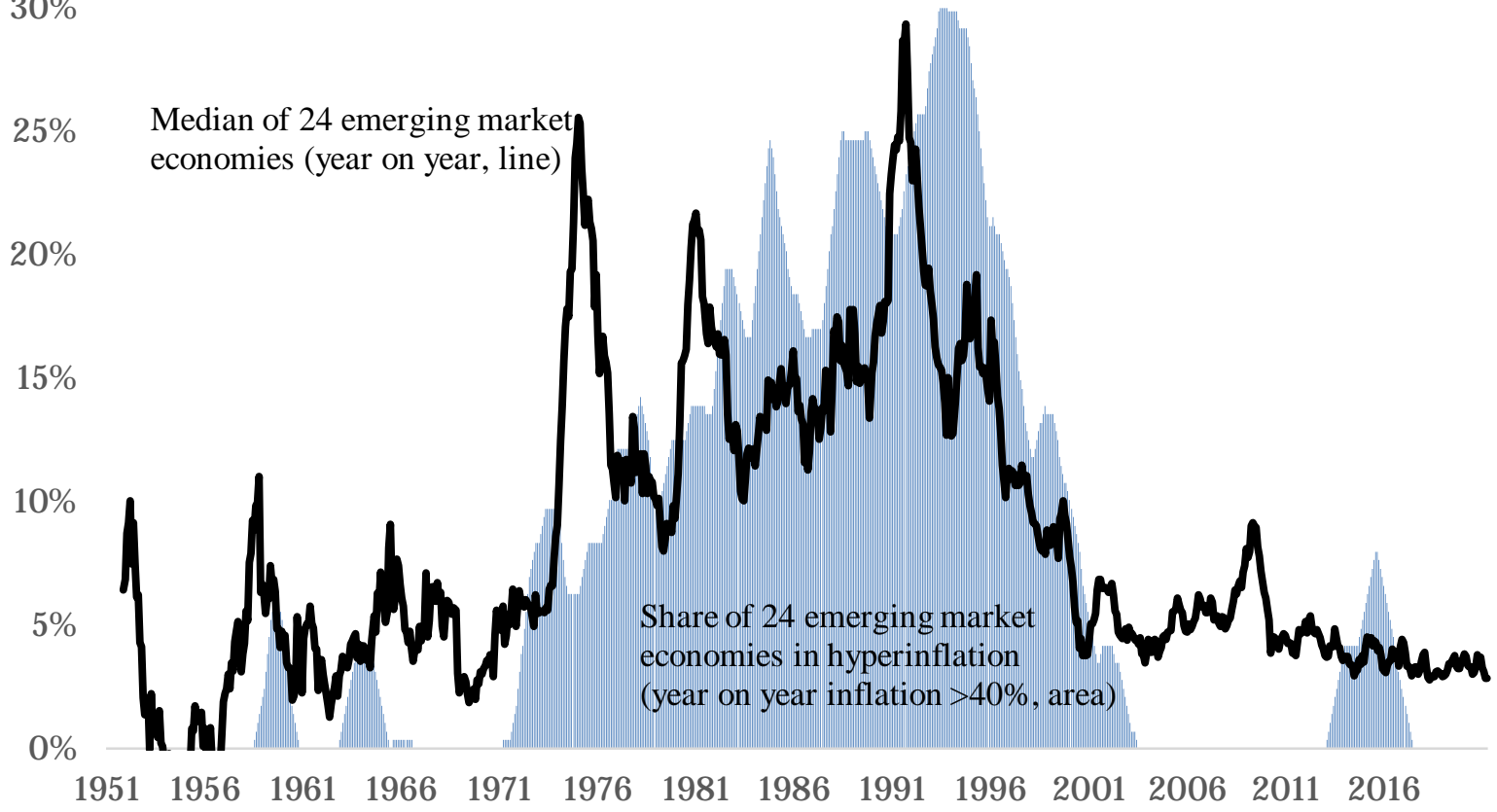

Source IFS, conference board, Federal Reserve Bank of St. Louis and the authors. 
notable case of hyperinflation in 2008, but isn’t typically classified as an EM). In terms of exchange rates, many emerging markets have bucked the G4's trend and moved to greater exchange rate flexibility and eschewing formal exchange rate targets.

Panel A of Figure 7 shows that the GFC and the monetary developments that followed revived the currency crash, with 6\% of all currencies crashing in 2008-9, and an additional 4\% during the proverbial “taper tantrum” of 2013, when the Federal Reserve slowed its asset purchases. The figure shows the share of all countries experiencing a currency crash, defined in this case as a decline of $12 \frac{1}{2} \%$ in their bilateral exchange rate with their anchor currency (see Ilzetzki, Reinhart and Rogoff 2019 on anchor classifications). Covid-19 saw only a handful (2\%) of currencies crashing. Compared with previous shocks, this is a pittance-roughly half a taper tantrum and nowhere close to the GFC. Panel B shows the generalized decline in hyperinflations, which is associated with much lower trend inflation in emerging markets overall. We will return to risk to the apparent resilience of emerging markets in the next section. ${ }^{14}$

\section{Risks to Extended Bretton Woods II}

At the time of this writing, exchange rate stability among advanced economies has persisted and other financial assets have stabilized as well. However, the pandemic is still unfolding, cases and death tolls continue to accumulate worldwide, and a second acute round of the pandemic remains a distinct possibility. What risks does the continued pandemic_or its aftermath—pose to the downward trend in exchange rate volatility and to the international monetary system more broadly? Of course, in addition to macroeconomic and especially monetary policy, outcomes depend on success in dealing with the virus, and how well the public is reassured that further extreme risks do not lie around the corner. ${ }^{15}$

\footnotetext{
${ }^{14}$ Exchange rate variability in some emerging markets has remained high during this period as many emerging market have opted for more flexible exchange arrangements. Kalemli-Özcan (2019) shows that variability in emerging market policy interest rates has declined in the $21^{\text {st }}$ century, but unlike high-income countries, this decline has somewhat faltered since 2014 and rates have been well above zero. Further, the comparison with high income countries is complicated due to risk premia, whose importance for emerging markets Kalemli-Özcan (2019) highlights.

${ }^{15}$ Kozlowski, Veldkamp and Venkateswaran (2020) argue that even if the pandemic ends by December 2020, the long-term effects of higher perceived tail risk will significantly impact investment and consumption for many years to come.
} 
Determining whether the current period of exchange rate stability will continue is highly speculative, so in this section we can only highlight some considerations. But we certainly don’t want to leave the reader with the impression that one can be highly confident in extrapolating Extended Bretton Woods II indefinitely into the future. For example, some notable differences between the current pandemic recession and the 2008 financial crisis suggest a distinct chance that the inflation, interest and exchange rate aftermath will eventually become much more volatile, even if markets presently heavily discount the possibility. ${ }^{16}$

One factor, to which we alluded earlier, is that aggressive central bank intervention has produced far more market liquidity this time around. In 2008, massive increases in bank reserves largely sat at the central bank and did not have a leveraged effect on broader monetary aggregates. This time, many markets are experiencing significantly higher liquidity, notably the dramatic rise in monetary aggregates in the United States, Europe, Japan and the UK, seen in Figure 8. The top panel shows that M2 has grown at an unprecedented rate since Covid-19, while the bottom panels shows that this monetary expansion has reflected in broader measures of liquidity (M3) and more globally. This is partially due to firms calling on lines of credit to have a war chest for the next spike of the pandemic, but in the United States, mortgage refinancing has also been important. It is an open question whether, as the economy heals, this higher liquidity will eventually bleed over into inflation, particularly if central banks remain concerned with low growth and high public and private sector debts. The Federal Reserve's new policy framework, which many other central banks are likely to follow, underscores that policymakers are now (rightly) willing to take more risks on inflation to promote growth.

A second key difference is that Covid-19 is a significant supply shock; whereas it has likely accelerated some important positive productivity shifts (more telecommuting and teleconferences), the medium-term effect could turn out to be quite negative. This is apparent in the stress on global supply chains and the fall in trade, which had already been growing at a slower rate than since the 2008 financial crisis. A considerable body of evidence has

\footnotetext{
${ }^{16}$ Inflation expectations collapsed at the onset of the Covid-19 crisis but have since recovered to pre-pandemic rates. Expectations remain below the Fed's 2\% target (see top panel of Figure A4 in the Appendix). At the same time, there are some indications of underlying inflationary pressures. Using scanner data in the United Kingdom, Jaravel and O'Connell (forthcoming) show that monthly inflation spiked to $2.4 \%$ in the first month of the lockdown. Cavallo (2020) argues that official figures understate inflation in 17 emerging and high-income economies, as they fail to consider shifting consumption patterns during the pandemic. The bottom panel of Figure A4 in the appendix shows an atypical divergence between food price inflation and CPI inflation, highlighting the current uncertainty in the effective inflation rate.
} 
Panel A: US M2

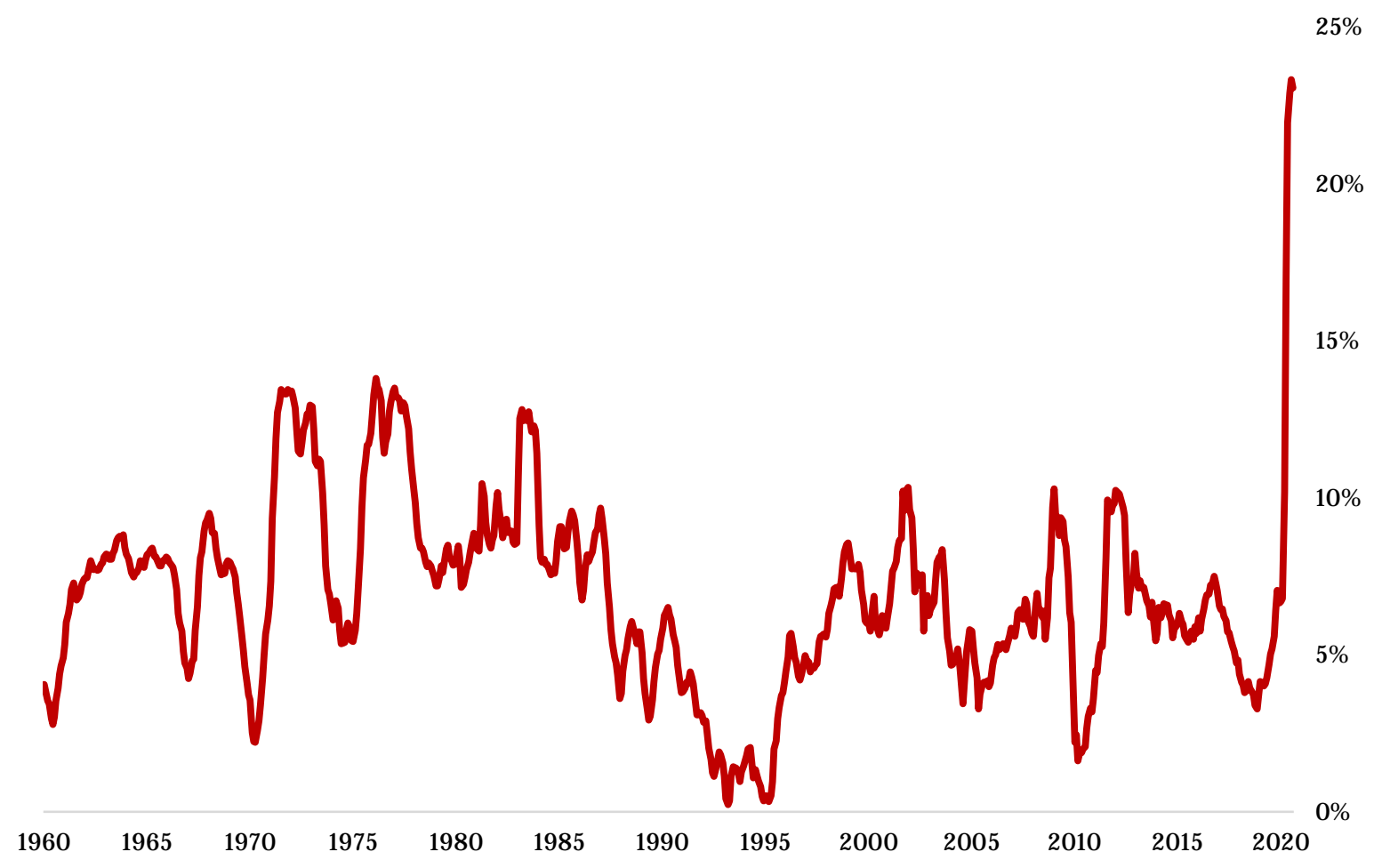

Panel B: Aggregate M3 for the US, Eurozone, Japan and UK

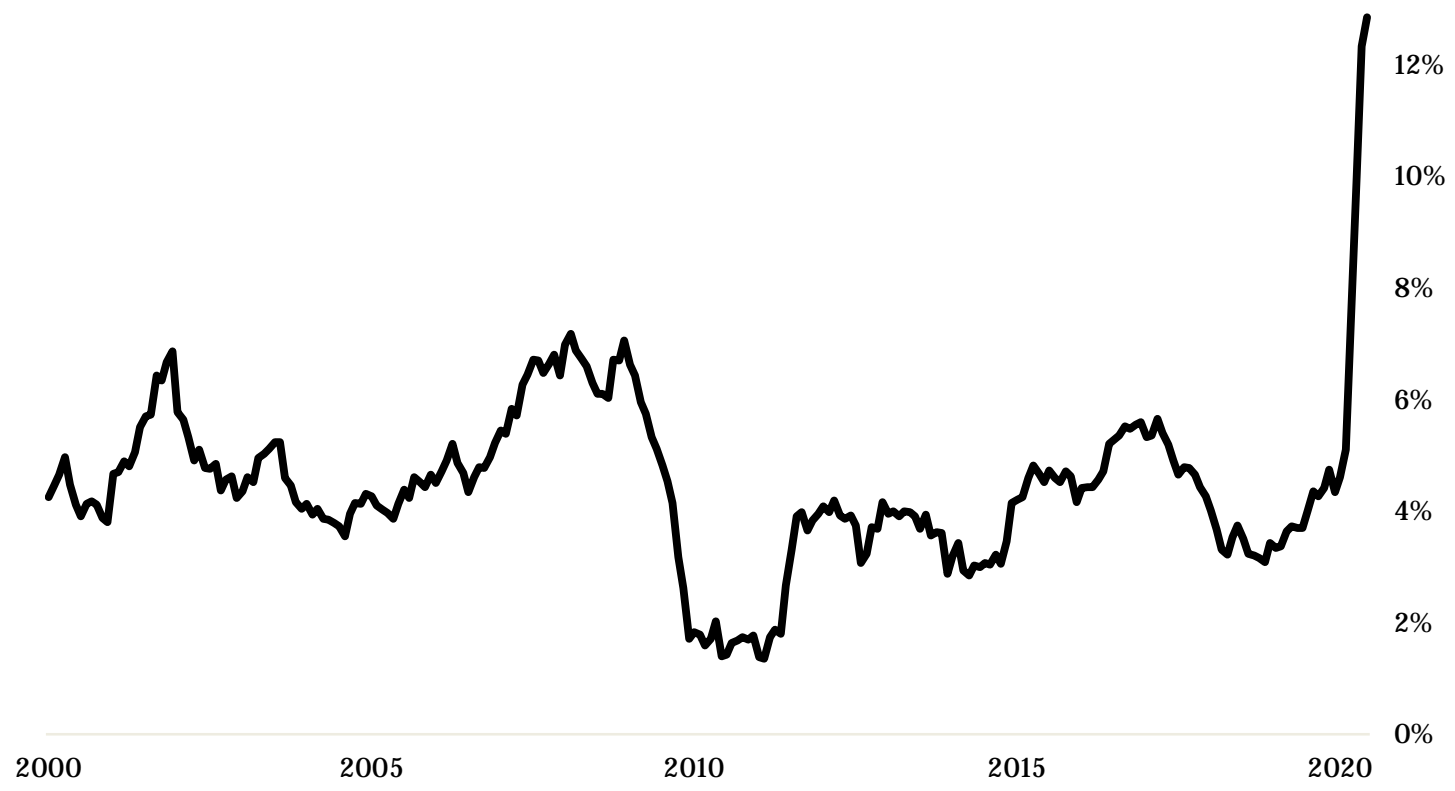

Sources: Federal Reserve Board, European Central Bank, Bank of Japan, Bank of England and the authors. 
accumulated that global factors have been a major reason for downside surprises in trend interest rates and inflation the past two decades (as suggested in Rogoff, 2003, and Kose et. al, 2018). Deglobalization, should it happen, could put the dynamic into reverse. Indeed, the massive ffective growth in the global labor force over the past four decades, particularly due to the integration of China and Eastern Europe, as well as an expansion of women into the labor force, was likely a major force in pushing down labor shares and prices. Even without deglobalization, demographics point to a declining effective global labor force unless India and Africa pick up the slack as China ages.

Covid-19 is also likely to lead to major domestic restructuring, away from consumer-facing businesses, which in turn could reverse the four-decade shift towards greater urbanization. Greater density produces production efficiencies but at the costs of heightened pandemic risks. Financial stress can also take a toll. Even with very generous Federal loans, many small businesses will not survive and there is likely to be huge damage in commercial real estate. Thus, it is important to be careful in making analogies to the deflationary 2008 financial crisis; the lasting supply effects here could be much more adverse.

Turning to history as a guide, we have already seen (Figure A2 in the appendix) that the international monetary system of the 21st century has by now outlived Bretton Woods. This may seem surprising since the Bretton Woods era is sometime viewed as running from after World War II until its collapse in the early 1970s, but in fact one can divide the regime into two distinct phases. The first, from the end of the war to the mid-1950s was characterized by high volatility of market exchange rates (as measured by active parallel markets across Western Europe) in face of high and volatile inflation. So although formally a period of fixed exchange rates, it was a very different regime than one with integrated capital markets, a unified exchange rate regime and low inflation. Bretton Woods's true heyday — the second phase from the mid-1950s to the late 1960s — was relatively short only arrived when inflation declined to low single digits, exchange markets were unified, and as the Euromarket began to develop.

Figure 9 shows the evolution of the international monetary system and of global inflation from 1960 to 2020. It combines world inflation (average inflation weighted by each country's share of world GDP, for over one hundred countries) with the average variation in G3 (US, Germany, and Japan) bilateral exchange rates (a synthesis of the two panels of Figure 1). The strong correlation between the level of global inflation and the variability of exchange rates is 


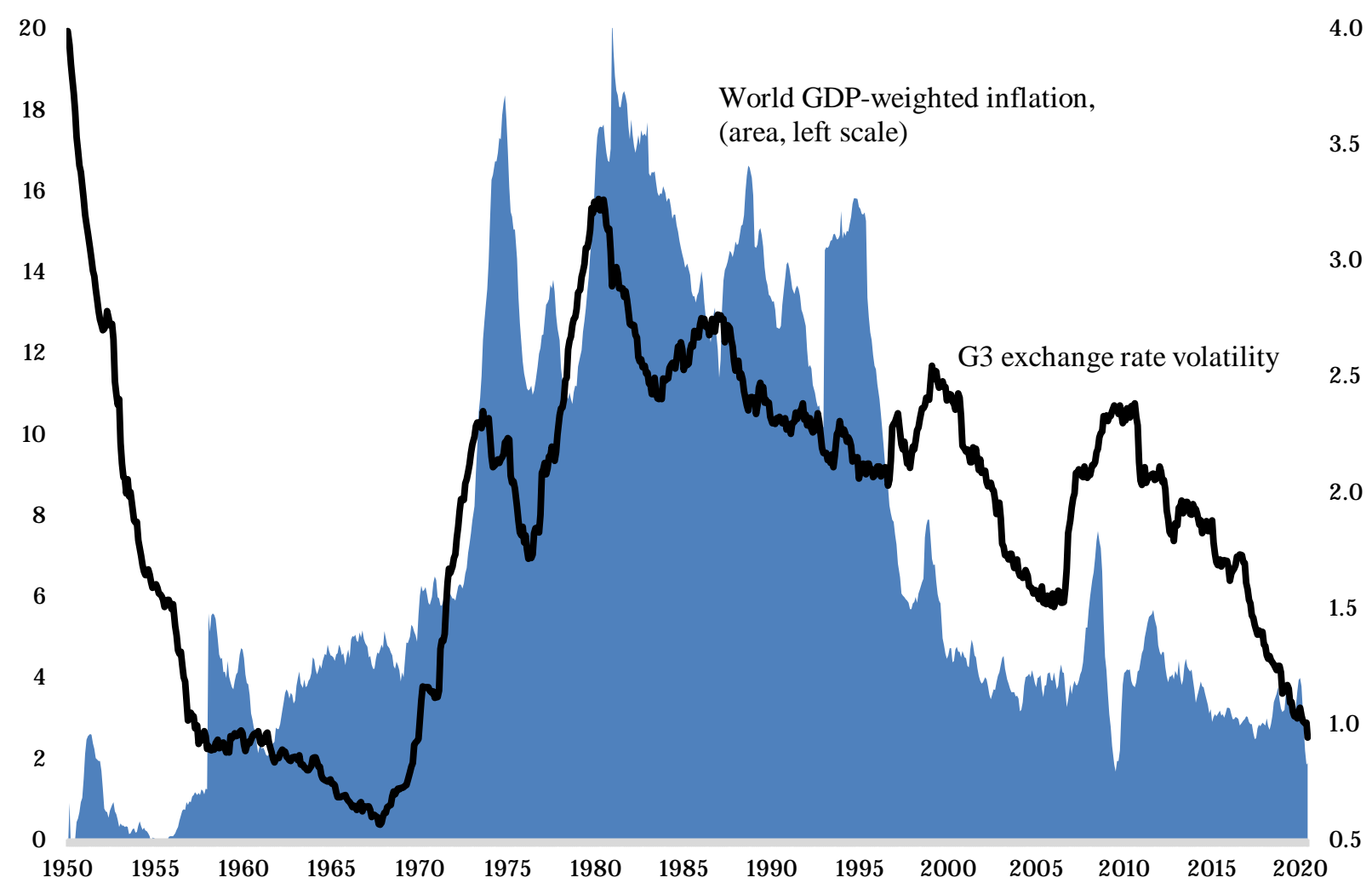

World inflation is calculated the average GDP-weighted year-on-year inflation. GDP weights are at 1990 GearyKhamis purchasing power parity. Individual country inflation rates capped at $100 \%$ to avoid excessive influence of outliers. G3 exchange rate volatility is given as the average four-year moving average of the monthly absolute value of exchange rate change among the three cross rates of the US dollar, euro (Deutschemark pre-1999) and yen. Sources: IFS, Conference Board and the authors.

immediately apparent, much as we highlighted for advanced economies alone. Note that the early sixties saw the nadir of global inflation although inflation differentials were higher. ${ }^{17}$

Bretton Woods' halcyon era formally ended when the US de-linked the dollar from gold in 1971, but as the figure shows, the system was already in decline by the late-1960s. The inflation surge in the early 1970s was the straw that broke the camel's back. It is not coincidental that the departure from the gold standard was part of a package of policies all announced in tandem on August 15, 1971. The package included price controls in attempt to limit already rising inflation

\footnotetext{
${ }^{17}$ In Figure 9, global inflation is calculated as a GDP-weighted average of those countries for which data were available in each month. Inflation rates in the 50s and 60s should therefore be compared to recent inflation rates with caution: The sample in the 60s contains far fewer developing countries and developing countries comprised a far smaller share of world GDP at the time. Nevertheless, it is interesting that exchange rates only began stabilizing in Bretton Woods in the deflationary and low interest rates years following the Korean War.
} 
and $10 \%$ tariffs on imported goods — another relevant parallel to today’s world of heightened trade tensions. ${ }^{18}$

This ushered in a third phase of the global exchange rate system, a "great de-anchoring”, with world inflation consistently in double digits and peaking at $20 \%$. We have seen that inflation was also very variable across high income countries and even more so when including developing countries, many of which experienced hyperinflation. ${ }^{19}$ This was also a period of high exchange rate volatility and multiple currency crashes (see Figure 7). It was only in the mid- to late-1990s that world inflation stabilized at moderate rates and inflation differences across countries diminished. This eco-system supported the emergence of the Bretton Woods II system, which has now morphed into the Extended Bretton Woods II system, thanks to the decline in G4 exchange rate variability documented in this paper.

Clearly, a surge in global inflation could pose a threat to the current international monetary order. Inflation targeting has been the de jure monetary framework of choice in the 21st century. The proliferation of independent central banks and inflation targeting regimes may well have anchored inflation expectations and contributed to the benign inflationary environment of the past two decades. However, inflation targeting has not yet faced a test commensurate with the challenges that led to the great de-anchoring of the 1970s. It may yet face one after Covid-19.

Another potential source of risk is the dramatic rise in global debt, both public and private. Sharply rising debt may well be perfectly benign given very low interest rates, but at the same time it can increase vulnerability to a loss of confidence. Theory suggests that an optimizing hegemon may be tempted to take advantage of global demand for its debt by sharply expanding issuance, taking the world from a "safe zone” to a risky “multiple equilibrium zone”. This can happen if the hegemon only takes into account risks to its own welfare and does not internalize the global costs of systemic breakdown. It is worth recalling that in the runup to the 2008 financial crisis, policymakers in the US and UK (whose financial firms were big beneficiaries of financial globalization) downplayed concerns expressed by other countries that their lax financial regulation could become a global problem.

\footnotetext{
${ }^{18} \mathrm{https}$ ://www.presidency.ucsb.edu/documents/address-the-nation-outlining-new-economic-policy-the-challenge-peace

${ }_{19}$ Our world inflation index caps countries' inflation at $100 \%$ to avoid disproportionate weight on extreme hyperinflations.
} 
Presumably, near-term risks to significantly higher US debt issuance remain low, but nevertheless consider Figure 10, which compares US borrowing in global markets to other major currency issuers. Remarkably, although the combined economic size of the other major advanced economies issuers considerably exceeds the size of the United States, the United States government has placed roughly has much public debt in global markets as all the others combined. Moreover, near term, even with Europe now issuing Eurobonds, US borrowing is likely to continue to outstrip the world.

Figure 10: Marketable Debt SeCurities, August 2020

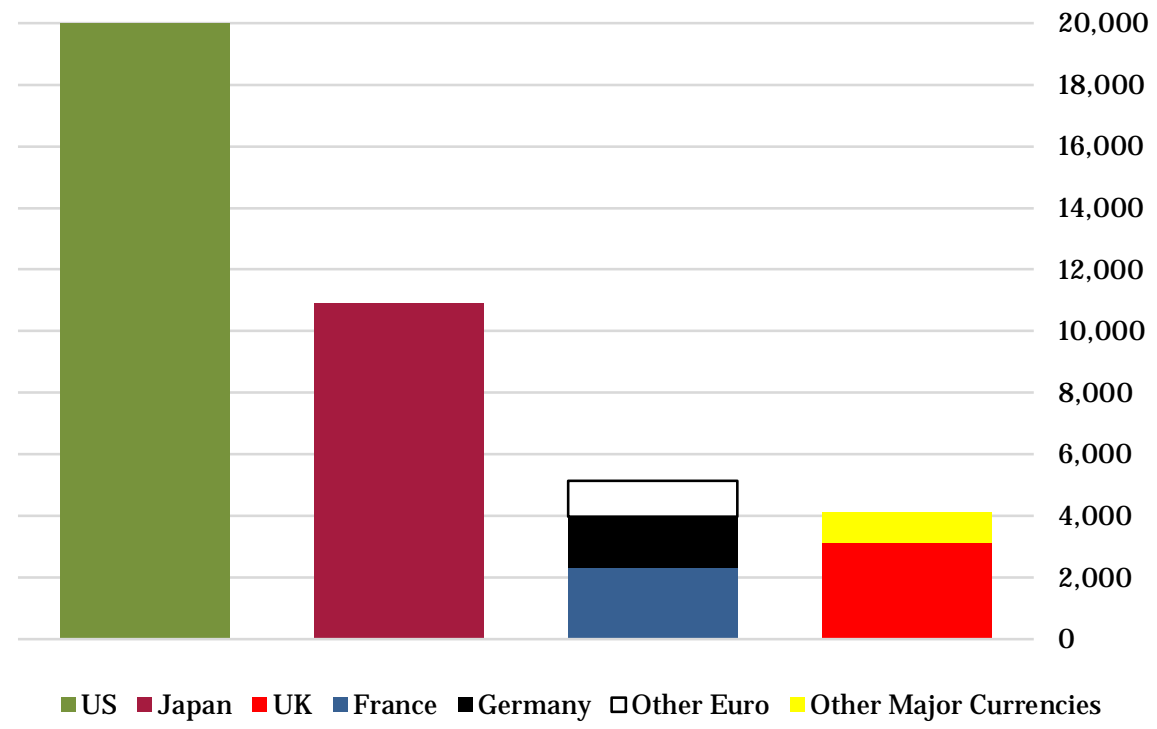

Marketable debt securities in billions of US dollars, August 2020 (June or July for some countries depending on data availability, converted at market rates of August 2018). Columns from the left to right: United States; Japan; highly rated Eurozone securities (Austria, Belgium, Finland, France, Germany, and the Netherlands; other major currencies (Australia, Canada, Sweden, Switzerland, and UK). China omitted due to lack of concurrent data. Source: national finance ministries and the authors.

Even if rising US debt levels eventually push it into a zone of greater fragility (that is, entering a multiple equilibria zone in a model such as Farhi and Maggiori 2018), economic theory tells us little about the timing of a loss of confidence, which could take a year or a century. Our own strong prior is that the near-term risks are likely very small and should remain so over the next several years. However, if US public debt continues to increasingly dominate global public debt markets — which are rapidly growing overall-the situation can change quickly and unexpectedly. It bears note that Yale economist Robert Triffin famously warned the US Congress in 1960 that there was a fundamental inconsistency between the growing size of 
foreign reserves of US dollars, and the shrinking backing in terms of gold reserves and US GDP (Triffin, 1964). Yet, the Bretton Woods system lived on for more than a decade.

The collapse of the interwar gold standard in the 1930s and the break-up of Bretton Woods in the early 1970s were times of great macroeconomic duress. The same need not be true next time, if there is a breakup of Extended Bretton Woods II, but the risks should not be underestimated.

Even without a breakdown at the core, the risks to emerging markets are immense, and unlike in the 1980s and 1990s, the spillovers to advanced economies, including the United States could be much greater this time. At purchasing power parity weights, emerging markets now account for roughly $60 \%$ of global GDP compared to just over $40 \%$ at the time Moreover, advanced economies and emerging markets today are linked by complex global supply chains that almost certainly have a big impact on productivity and prices in advanced economies, at least in the medium run. It would be hyperbole to say that emerging markets are the canary in the coal mine for global inflation and exchange rate stability, but it would be complacent to dismiss the transmission risks.

Spreads on emerging market sovereign bonds spiked in March, currencies from the Brazilian real (down 24\% year to date) to the Turkish Lira (down 60\% since 2016) collapsed, and several central banks expended as much as a quarter of their reserves to prop up their currencies. The Institute of International Finance's daily capital flows showed capital flowing out of emerging markets from February to April 2020 in quantities five times greater than in the similar timeframe following the collapse of Lehman Brothers in 2008. Outflows have since abated and capital flows have resumed into some markets. Emerging market exchange rates have moved, but in most cases by less, so far, than in the 2008 crisis. But this could change.

Indeed, the crisis is still unfolding; even if a vaccine is found, emerging markets may not benefit for years. In the meantime, they face many of the same fiscal, social and political stresses as advanced economies. The long period of macroeconomic stability in emerging markets is at risk. Figure 11 assesses some of the risk factors hovering in the background of the relatively benign outcomes in emerging markets to date. It shows a scatter plot across countries categorized as "emerging markets" by the IMF, comparing the exchange rate decline from February $1^{\text {st }}$ to 
Figure 11: Pre-EXISTING CONDITIONS AND COVID-19 DEVALUATION: EMERGING MARKETS Panel A: Public Debt to GDP

Panel B: Deficit to GDP

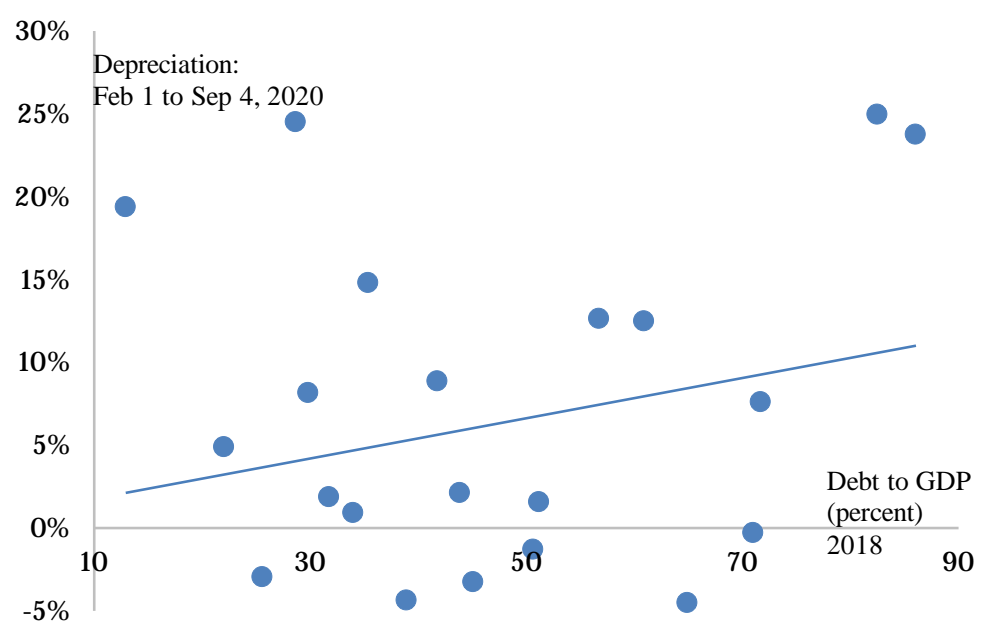

Panel C: Corporate Debt to GDP
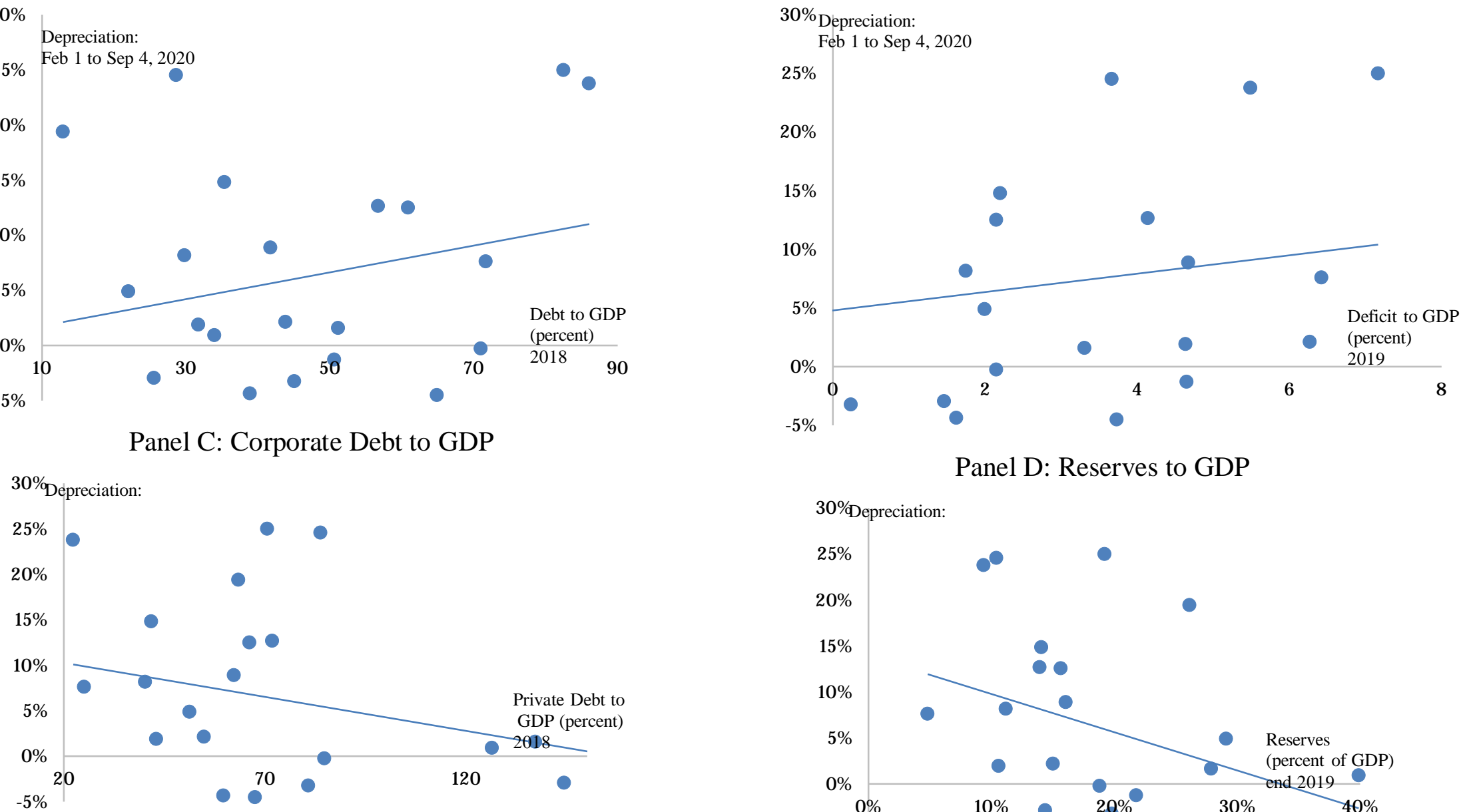

Panel D: Reserves to GDP

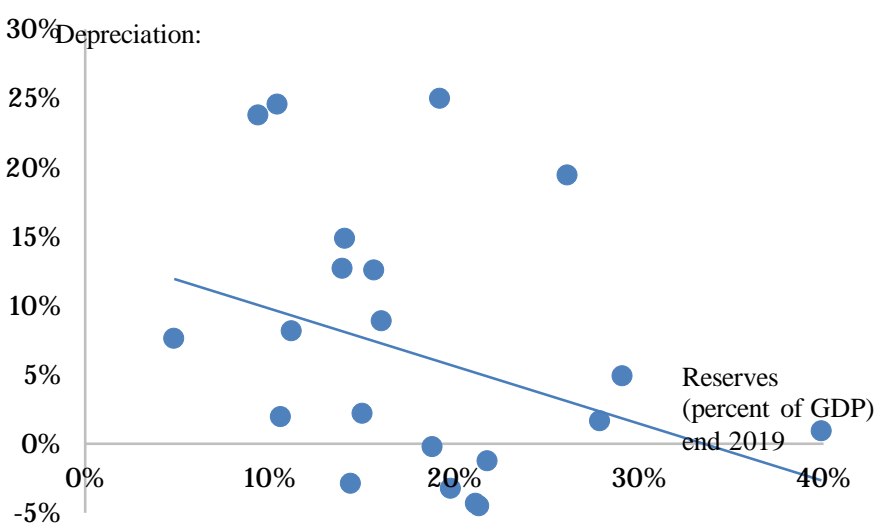

Source: IMF Global Debt Database, Bloomberg, and the authors. 
date with a number of "pre-existing conditions" prior to the Covid-19 crisis. Much has been written on the importance of private sector debt as a predictor of financial crisis, but interestingly we find no correlation between the ratio of private sector debt to GDP and the currency sell-off during Covid-19 (panel C of the figure). This is separately true for corporate debt and household debt and the growth of private sector debt in recent years (not shown in the figure).

In contrast, the top row of Figure 11 (panels A and B) show that fiscal conditions are correlated with the emerging exchange rate decline in recent months. Countries with higher ratios of debt to GDP and higher deficits to GDP (both measured in 2019) saw greater exchange rate declines since February 2020. While the sample size is small and there is much variation in the data, the correlations are at least suggestive that markets are more sensitive to emerging markets' fiscal positions than they are to private sector balance sheets, at least so far.

The $21^{\text {st }}$ century saw the greatest accumulations of central bank foreign exchange reserves on record. Central bank foreign exchange reserves have increased nearly 8-fold this century from \$1.4 trillion in 2000 to \$11 trillion today. Panel D of Figure 11 shows that the relative stability of emerging market exchange rates should be viewed in the context of a large deployment of these reserve holdings to prop up EM exchange rates. Countries entering the crisis with larger reserve holdings relative to GDP saw lower exchange rate declines suggesting that reserves served as a buffer against exchange rate volatility. Most dramatic is the case of Turkey, whose central bank has already expended $40 \%$ of its foreign exchange reserves since the beginning of the year. But the reserve sell-off has been widespread with countries ranging from Egypt to Ecuador (showing FX reserves declining by $20 \%$ and $30 \%$, respectively) to support their currency. ${ }^{20}$

\section{Conclusions}

This paper highlights a significant but not well-known fact about the global exchange rate system: the increasing stability at its core. The Bretton Woods II regime, first highlighted in an insightful series of papers by Dooley, Folkerts-Landau and Garber (2003), stressed stability between the dollar and the rapidly growing countries of Asia. Bretton Woods II has now

\footnotetext{
${ }^{20}$ Figure A4 in the appendix shows the same figure comparing emerging market sovereign spreads (over 10-year US Treasuries) and shows similar patterns.
} 
morphed into Extended Bretton Woods II, including the United States, Europe, and Japan. By some measures, Extended Bretton Woods II has surpassed Bretton Woods I in stability, durability and breadth. One only has to recall that during Bretton Woods I, the second largest economic region in the world, the Soviet Bloc, did not participate and was not pegged to the dollar. By contrast, not only has the euro dollar rate become relatively stable, but exchange rate instability among the 19 countries of the eurozone has been completely eliminated.

Just as Bretton Woods I came to a crashing end, there are risks to Extended Bretton Woods II. The risks are most apparent in emerging markets, whose share of global GDP has risen dramatically since 1980 and are linked to advanced economies both through demand and through increasingly important global supply chains. External debt levels (public and private) in emerging markets were already rising to risky levels in the years prior to the pandemic and are significant source of risk now with uncertain output and falling global trade. Although many are able to tap today's extremely liquid markets, the interest costs are high, and new borrowing has not been enough to refinance loans coming due and to replace portfolio outflows. Arguably, several debtor countries are effectively liquid (thanks to especially to extraordinary actions by the Fed and the ECB), but insolvent.

Moreover, even after the full-blown health crisis is tamed, Covid-19 could well leave a lasting negative effect on the supply side of the economy. Globalization could be dramatically rolled back, with some travel restrictions likely to remain in place for years, global supply chains consolidated to strengthen resilience, and political ferment threatening to amplify these effects, regardless of election outcomes. As the virus lingers, the explosion of small business bankruptcies could strengthen monopolies and reduce pressures for innovation. Although central banks have extended broad guarantees, financial fissures could start expanding. Even if the current low inflation dynamic persists for many more years, there is non-trivial risk that eventually the mix of highly expansive monetary and fiscal policy in the face of a long-term adverse supply shock could upend the inflation calm of recent decades. Massive shocks to the global economy can produce turning points. Needless to say, the risks are difficult to assess, but we have argued that despite the preternatural calm in exchange rate markets, this to can come to an end, just as the Great Moderation did in 2008 and the Second Great Moderation did in 2020.

Enhanced stability of the global exchange rate system is hardly a problem. Indeed, the longerterm trend decline in core exchange rate volatility likely reflects the global shift to having 
independent, technocratic central banks. But the more recent decline in volatility since 2014 and even more so in the face of the Covid-19 pandemic still needs to be diagnosed. We have argued that the recent trend more likely reflects the paralysis of monetary policy at the zero bound and there are reasons to be concerned that today's stability might mask fragilities, not strengths. The exchange rate is a portmanteau measure of relative national macroeconomic and financial shocks, and the current low pressure reading needs to be studied further before being declared an unalloyed triumph of modern independent central banks. 


\section{References}

Bai, Jushan and Pierre Perron "Estimating and Testing Linear Models with Multiple Structural Changes,” Econometrica 66(1), 1998.

Cavallo, Alberto, “Inflation with Covid Consumption Baskets,” NBER Working Paper 27352.

Dooley, Michael, David Folkerts-Landau and Peter Garber, “An Essay on the Revived Bretton Woods System,” NBER Working Paper 9971, 2003

Dornbusch, Rudiger. “Expectations and Exchange Rate Dynamics.” Journal of Political Economy 84, no. 6: 1161-176, 1976.

Eichengreen, Barry, Exorbitant Privilege: The rise and fall of the Dollar and the Future of the International Monetary System. (Oxford, UK: Oxford University Press, 2011).

Farhi, Emmanuel and Matteo Maggiori, (2017). “A Model of the International Monetary System” Quarterly Journal of Economics 131.

Gabaix, Xavier and Matteo Maggiori (2015). "International Liquidity and Exchange Rate Dynamics.” Quarterly Journal of Economics 130(3): 1369-1420.

Gopinath, Gita, “The International Price System,” Jackson Hole Symposium (Federal Reserve Bank of Kansas City, 2015).

Ilzetzki, Ethan, Carmen M. Reinhart, and Kenneth Rogoff, "Country Chronologies and Background Material to Exchange Rate Arrangements into the $21^{\text {st }}$ Century: Will the Anchor Currency Hold?,” NBER Working Paper No 23135, 2017.

Ethan Ilzetzki, Carmen M Reinhart, and Kenneth S Rogoff, "Exchange Arrangements Entering the TwentyFirst Century: Which Anchor will Hold?,” The Quarterly Journal of Economics, Volume 134, Issue 2, May 2019, Pages 599-646.

Ethan Ilzetzki, Carmen M Reinhart, and Kenneth S Rogoff, "Why is the Euro Punching Below its Weight?,” forthcoming in Economic Policy.

Itskhoki, Oleg and Dmitry Mukhin, “Exchange Rate Disconnect in General Equilibrium,” working paper, 2019a.

Itskhoki, Oleg and Dmitry Mukhin, “Mussa Puzzle Redux,” working paper, 2019b.

Ilzetzki, Ethan, Carmen M. Reinhart, and Kenneth Rogoff, "Exchange Arrangements Entering the $21^{\text {st }}$

Century: Which Anchor Will Hold?” Quarterly Journal of Economics 134 (2): 599-646, 2019.

Ilzetzki, Ethan, Carmen M. Reinhart, and Kenneth Rogoff, "Why is the Euro Punching Below its Weight?” Economic Policy, 35 (3), 2020.

Jaravel, Xavier and Martin O’Connell, “Real-Time Price Indices: Inflation Spike and Falling Product Variety during the Great Lockdown," forthcoming in the Journal of Public Economics.

Kalemli-Özcan, Şebnem “US Monetary Policy and International Risk Spillovers,” in Jackson Hole Symposium (Federal Reserve Bank of Kansas City, 2019).

Kozlowski, Julian, Laura Veldkamp and Venky Venkateswaran, “Scarring Body and Mind: The Long-Term Belief Scarring of Covid-19," paper presented at August 2020 Kansas City Federal Reserve Jackson Hole conference on "Navigating the Decade Ahead: Implications for Monetary Policy."

Lilley, Andrew and Gianluca Rinaldi, “Currency Betas and Interest Rate Spreads,” Mimeo, Harvard University, July 2020.

Meese, R., and Kenneth Rogoff, "Exchange Rate Models of the Seventies. Do They Fit Out of Sample?” Journal of International Economics 14, 1983. 
Maggiori, Matteo, Brent Neiman, and Jesse Schreger, “International Currencies and Capital Allocation,” Journal of Political Economy, forthcoming.

Miranda-Agrippino, Silvia and Hélène Rey “U.S. Monetary Policy and the Global Financial Cycle,” The Review of Economic Studies, rdaa019.

Obstfeld, Maurice and Kenneth Rogoff. Foundations of International Macroeconomics. Cambridge, MA: MIT Press, 1996.

Rey, Hélène, “Dilemma not Trilemma: The Global Financial Cycle and Monetary Policy Independence,” in Jackson Hole Symposium (Federal Reserve Bank of Kansas City, 2013).

Rogoff, Kenneth, “Impact of Globalization on Monetary Policy,” in Jackson Hole Symposium (Federal Reserve Bank of Kansas City, 2006).

Schwert, G. William. 1990. “Indexes of U.S. Stock Prices from 1802 to 1987.” Journal of Business 63 no. 3 : $399-442$.

Shiller, Robert, Irrational Exuberance. Princeton, NJ: Princeton University Press, 2005.

Stavrakeva, Vania and Jenny Tang, "Survey-based Exchange Rate Decomposition. New Methodology and New Facts.” Mimeo, London Business School October 2020.

Triffin, Robert, "The Evolution of the International Monetary System: Historical Reappraisal and Future Perspectives,” Princeton Studies in International Finance 12, 1964. 


\section{Appendix Figures}

\section{FIGURE A1: RMB/USD AND RMB/EUR VOLATILITY}

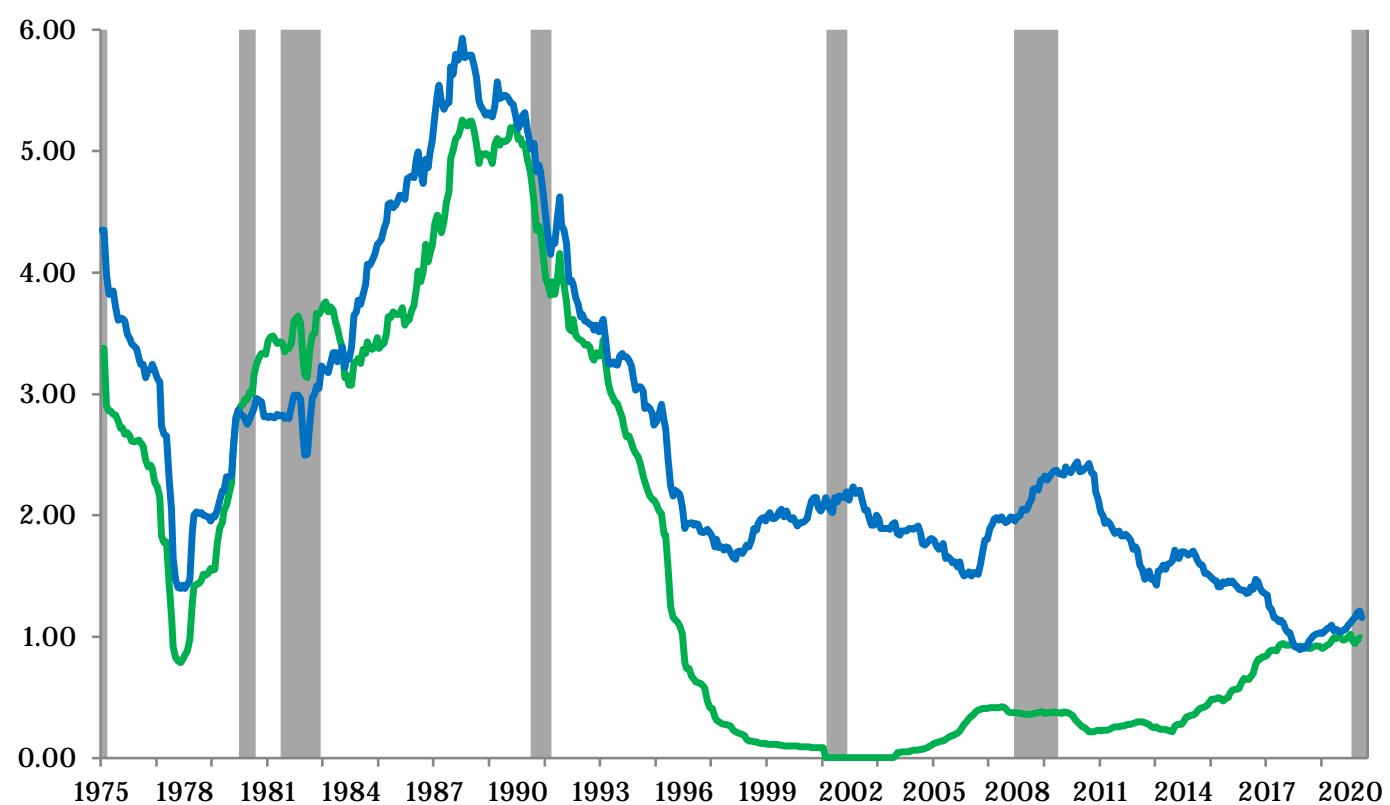

The figure shows the four-year moving average of the absolute value of month on month exchange rate change. Top blue line: RMB-euro. Bottom green line: RMB-dollar. Source: International Finance Statistics and the authors.

FigurE A2: G4 CURRENCY VOLATILITY: 1950-1970 AND 2000-2020

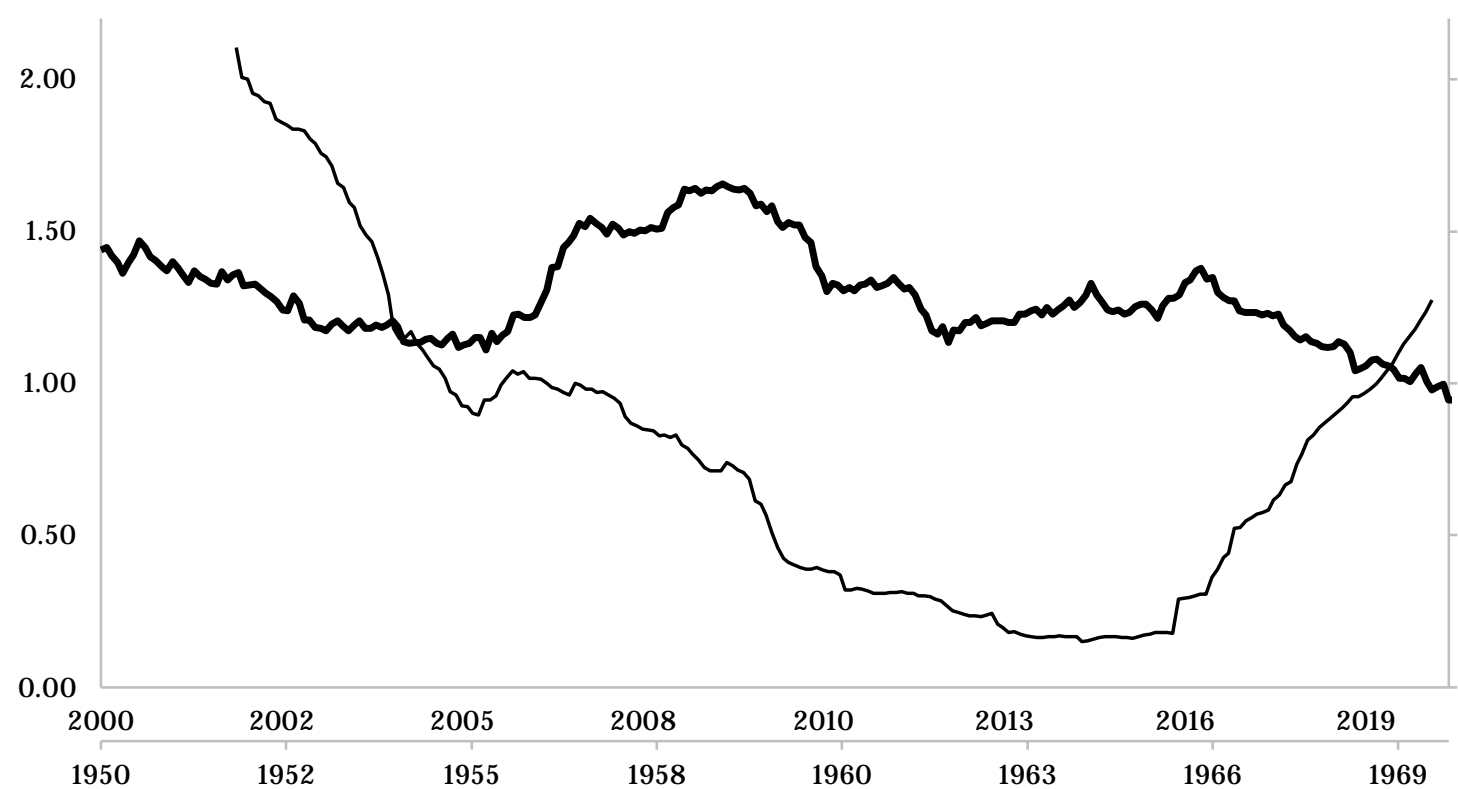

The figure shows the four-year moving average of the average absolute value of month on month exchange rate change of 3 top currencies against the US dollar. Thick line: 2000-2020, euro, yen, and renminbi. Thin line: 19501970, Deutschemark, UK pound and French franc. Source: International Finance Statistics and the authors. 


\section{Figure A3: CURRENCY VOLATILITY OF REMAINING G10 CURRENCIES}

Panel A: UK Pound

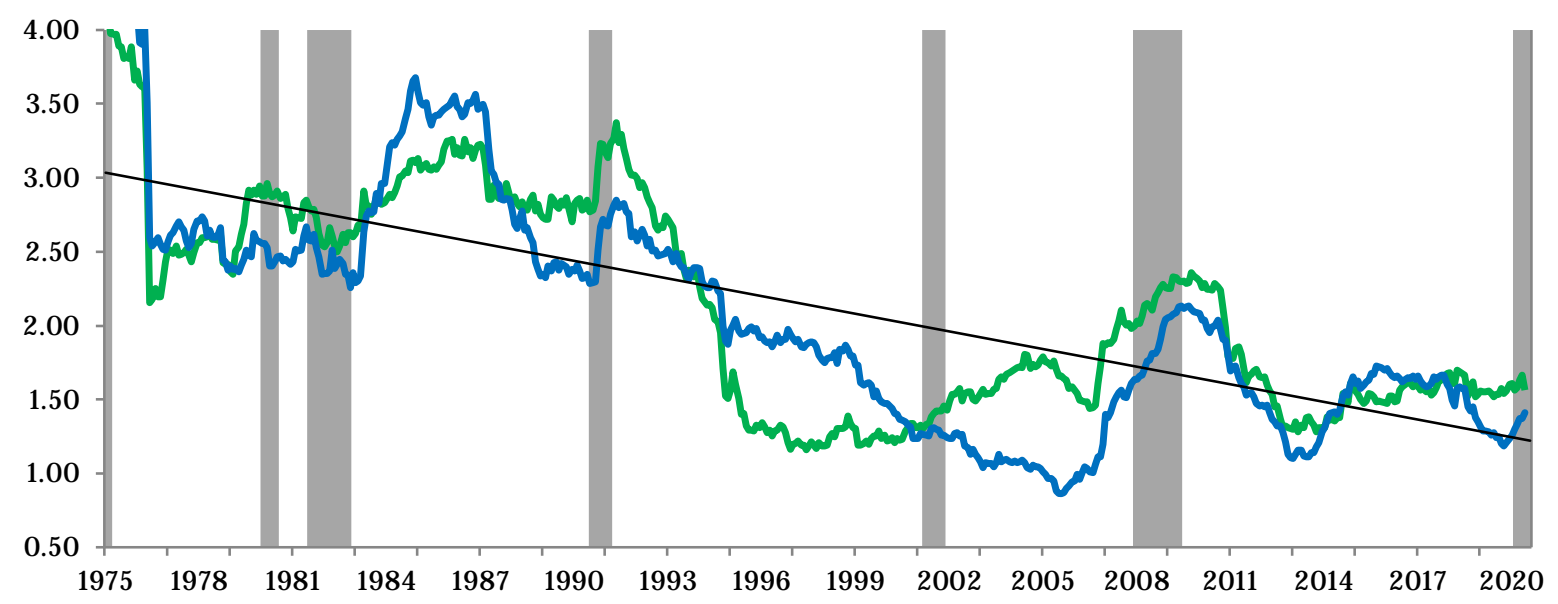

Panel B: Australian Dollar

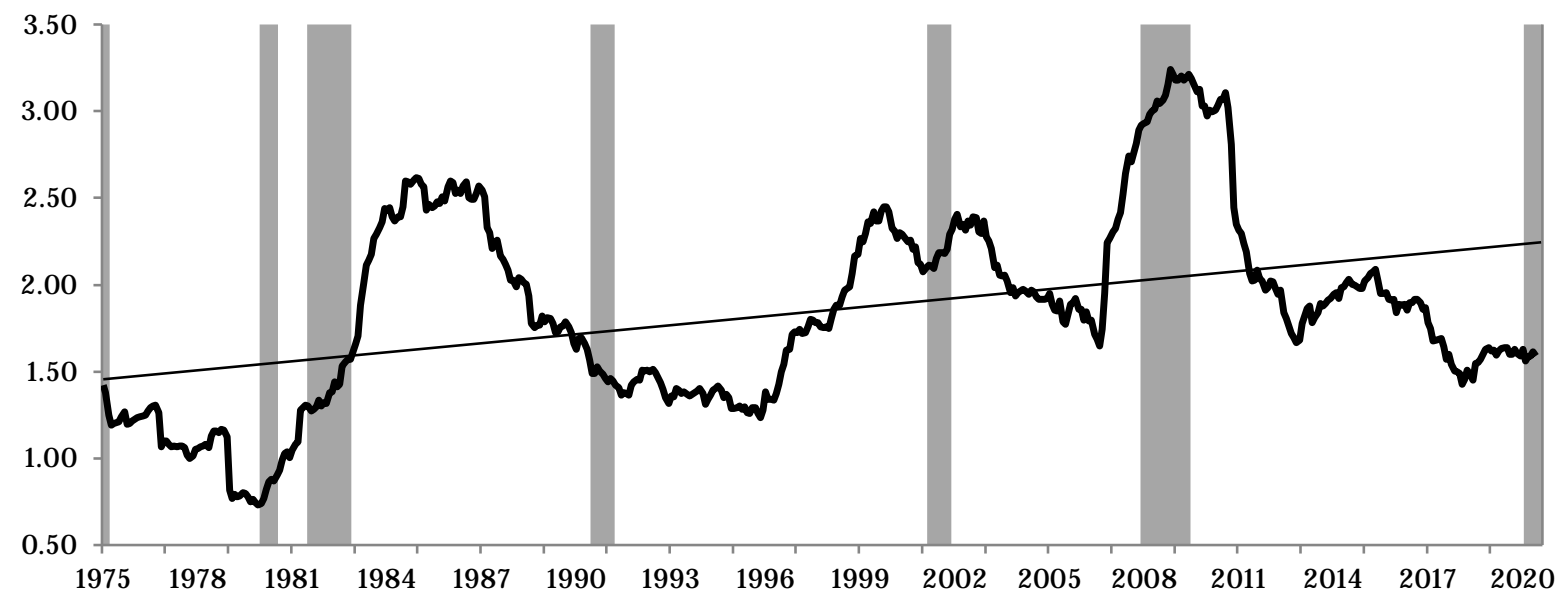

Panel C: Canadian Dollar

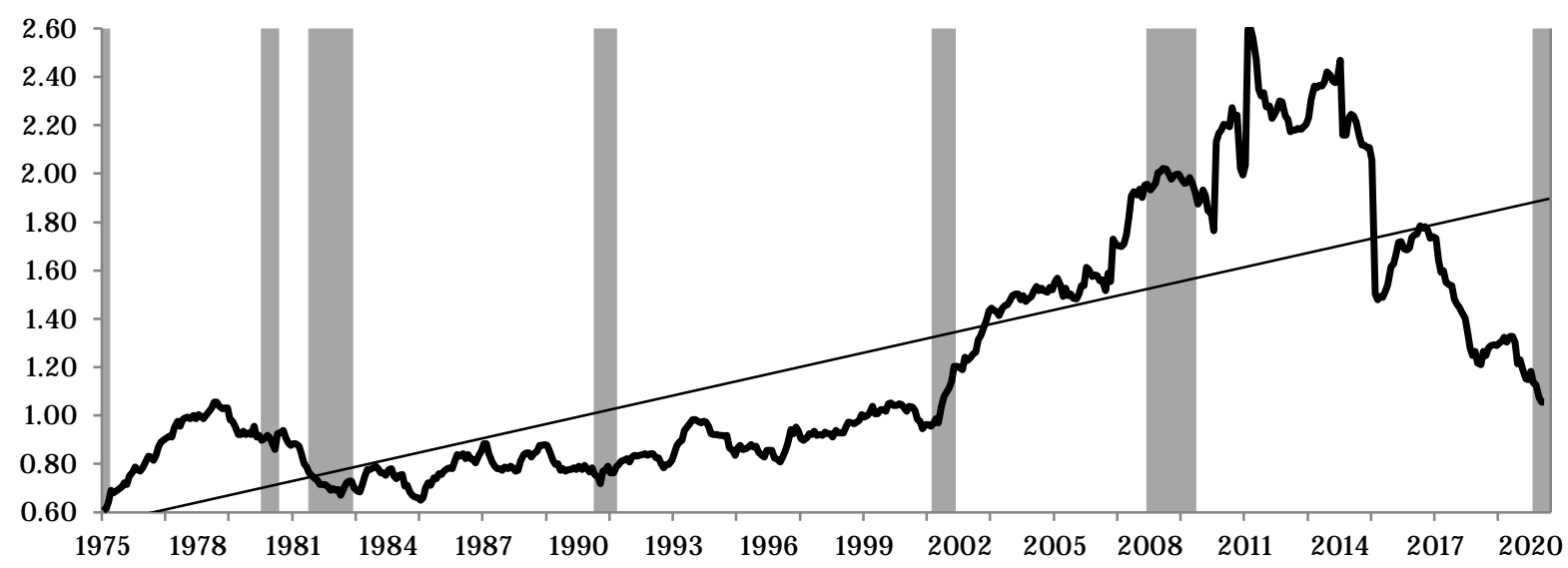

The figure shows the four-year moving average of the average absolute value of month on month exchange rate change of various currencies against the dollar (unless otherwise specified below). Panel A: UK pound. Blue line: against the euro, green line: against the US dollar. Panel B: Australian dollar. Panel C: Canadian dollar. Source: International Finance Statistics and the authors. 

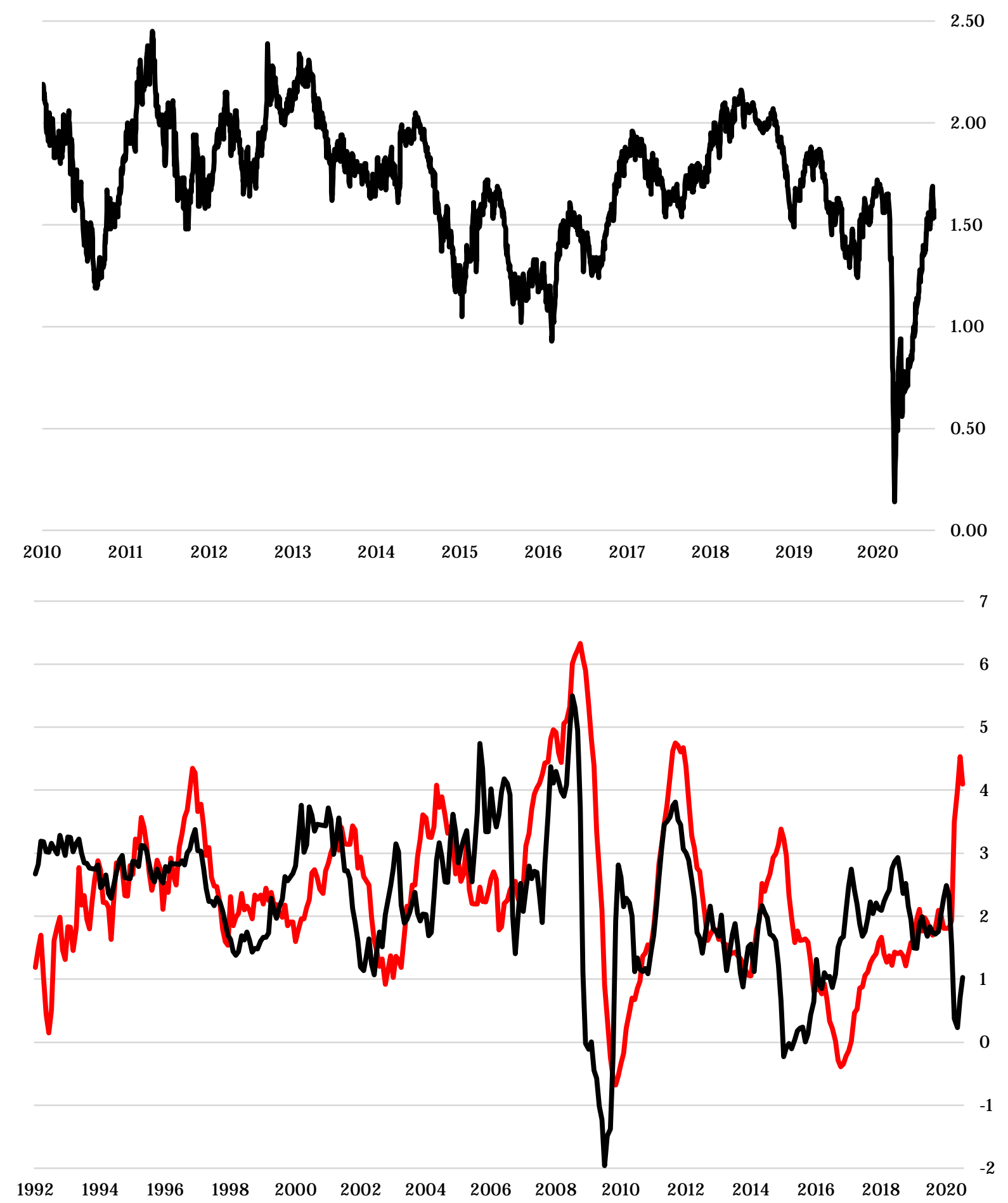

The top panel shows annual inflation expectations for the following 5-years, based on the difference between yields on 5-Year Treasury Constant Maturity Securities and 5-Year Treasury Inflation-Indexed Constant Maturity Securities. The bottom panel shows inflation of food prices (thick red line) and the consumer price index (thin black line) for US urban consumer. Sources: Federal Reserve Bank of St. Louis and the Bureau of Labor Statistics. 